edukafé

documentos de trabajo de la Escuela

Cali, Colombia

ISSN 2711-2799 (en línea)
ICESI

número 2

Mayo 2018

\title{
Proyecto Cinemotecnia de Cali: Guión Investigativo-Museológico
}

Danilo Duarte

Profesor Departamento de Humanidades Universidad Icesi

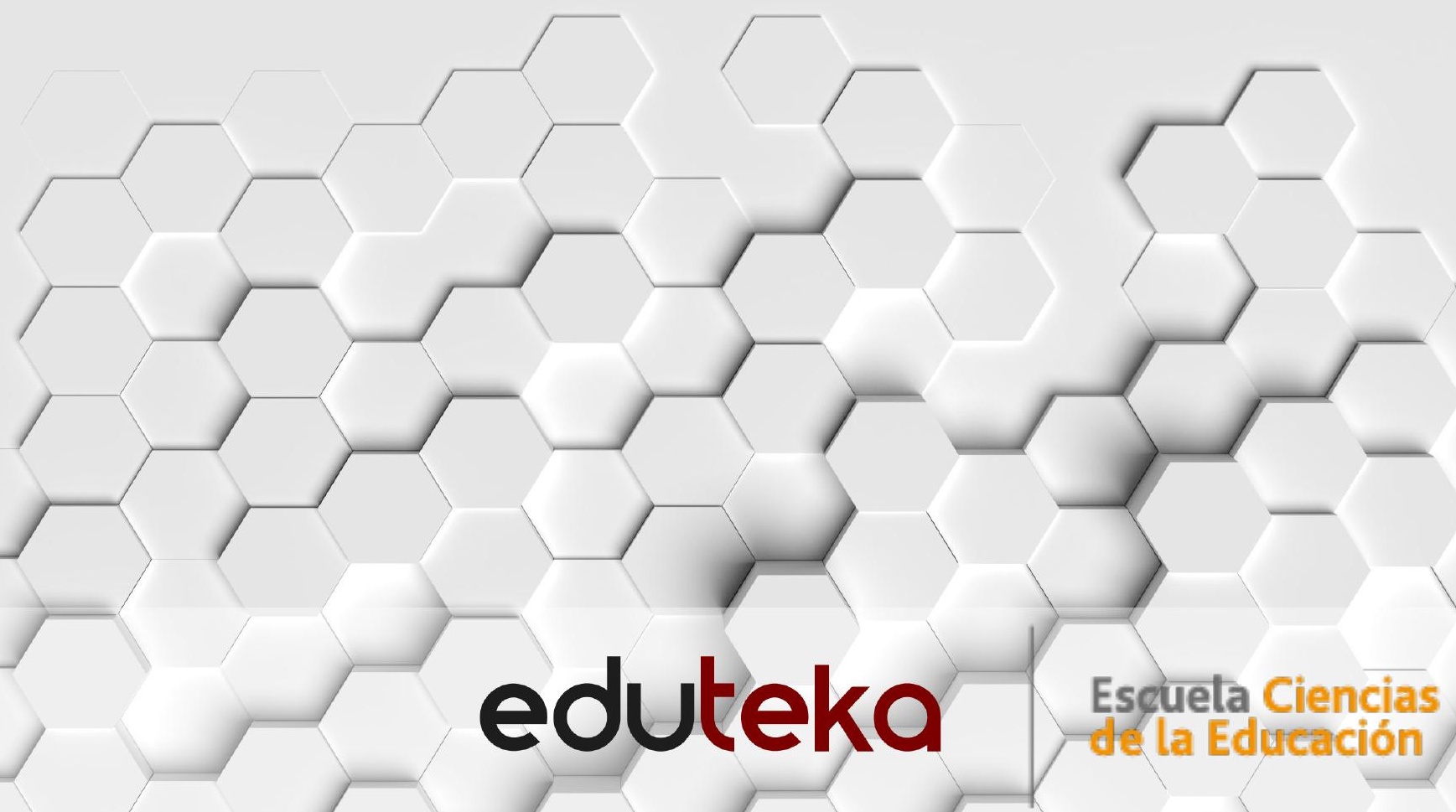


Número 2 • Mayo 2018

ISSN: 2711-2799 (en línea)

DOI: http://doi.org/10.18046/edukafe.2018.2

Rector: Francisco Piedrahita Plata

Secretaria general: María Cristina Navia Klemperer

Director académico: José Hernando Bahamón Lozano

Directora de la Escuela de Ciencias de la Educación: Ana Lucía Paz Rueda

Director del Centro Eduteka: Alejandro Dominguez Z.

Editor del portal Eduteka: Juan Carlos López-García • http://eduteka.icesi.edu.co

\section{Comité Editorial}

Ana Lucía Paz Rueda

Diana Margarita Díaz

Hoover Delgado Madroñero

Jhonny Segura

José Darío Saenz
José Hernando Bahamón Lozano

Juan Carlos López-García

Viviam Stella Unas Camelo

Enrique Rodriguez C.

Rafael Silva
Vladimir Rouvinski José Benito Garzón M. (Unicatólica)

Edición: Centro Eduteka

Editorial Universidad Icesi - Coordinación editorial: Adolfo A. Abadía

editorial@icesi.edu.co•https://www.icesi.edu.co/editorial

Diseño editorial y diseño portada: Juan Carlos López-García

Diseño del logo edukafé: Boris Sánchez Molano y Carlos Andrés Ávila

Imágenes de portada y contraportada: Magic Creative • Tokyo/Japan • pixabay.com

Universidad Icesi

Centro Eduteka

Escuela de Ciencias de la Educación (ECE)

Calle 18 No. 122-135 Pance • Cali - Colombia

Teléfono: +57 (2) 5552334 • Fax: +57 (2) 5551441

jclopez@icesi.edu.co•http://eduteka.icesi.edu.co/articulos/edukafe

Favor citar este documento de trabajo de la siguiente forma:

Duarte, Danilo (2018). Proyecto Cinemotecnia de Cali : Guión Investigativo-Museológico. Edukafé, Documentos de trabajo de la Escuela, No. 2. Cali: Universidad Icesi. Recuperado, el 25 de Mayo de 2018, de Eduteka: http://doi.org/10.18046/edukafe.2018.2

El Centro Eduteka no se hace responsable de las ideas expuestas, los modelos teóricos presentados o los nombres aludidos por el(los) autor(es) de los artículos publicados en la colección edukafé. El contenido de esta publicación es responsabilidad exclusiva del(Ios) autor (es), y no reflejan la opinión de las directivas de la Universidad Icesi, del Centro Eduteka, de la Escuela de Ciencias de la Educación (ECE), o de los editores de EDUKAFÉ - DOCUMENTOS DE TRABAJO DE LA ESCUELA

Licencia Creative Commons • Atribución/No-comercial/Compartir-igual

Esta licencia le permite distribuir, remezclar, retocar, y crear a partir de este este documento de modo no comercial, siempre y cuando se dé el crédito explícito a su(s) autor(xs) y a la Universidad Icesi y se licencien las nuevas creaciones bajo las mismas condiciones. 


\section{Contenido}

\section{Advertencia, ¿Qué se puede encontrar en este documento?}

Guión temático

Guión científico

Guión curatorial

Bibliografía

\section{edukafè}

"Frente a una taza con café se piensa, pero también se discute, se recuerda o se argumenta. Frente a la taza con café se columbra, se reflexiona, se sueña, se imagina, se escribe, se conversa... Y el café, el misterioso café escucha, profetiza, atestigua, aconseja, da fe, observa, asiente..."

Gustavo Máynez Tenorio

\section{http://eduteka.icesi.edu.co/articulos/edukafe}

Este documento de trabajo hace parte de la colección "edukafe" consistente en una serie de "working papers" escritos y publicados por profesores de la Escuela de Ciencias de la Educación de la Universidad Icesi con los que se busca apoyar la reflexión y la investigación en educación. Estos documentos pueden considerarse como "provisionales" y se publican bajo licencia Creative Commons (BY-NC-SA) para así estimular el debate académico entre diversos actores de la educación. Debate que puede tomar la forma de conversación, discusión, recuerdo, argumento, reflexión, sueño, escritura o conjetura; ojalá, frente a muchas tazas con café humeante.

Tal como lo plantea Marin-Garcia \& Garcia-Sabater (2010), los documentos de trabajo tienen como finalidad facilitar el acceso al debate académico de avances y resultados de trabajos de investigación, así como de fragmentos de investigación que posteriormente se pueden convertir en artículos científicos. De esta manera, estos trabajos académicos provisionales se vuelven citables y por tanto protegidos del plagio de ideas escritas y publicadas en versiones preliminares, sin menoscabo de ser divulgadas en los medios digitales ofísicos que su autor considere adecuados.

* Marin-Garcia, Juan \& Garcia-Sabater, José (2010). Los Working Papers al servicio de la escritura productiva. Working Papers on Operations Management. 1(1). doi:10.4995/wpom.v111.790 


\title{
Proyecto Cinemotecnia de Cali: Guión Investigativo- Museológico
}

\author{
Danilo Duarte * \\ Profesor Departamento de Humanidades \\ Universidad Icesi
}

\section{Advertencia, ¿Qué se puede encontrar en este documento?}

El trabajo museográfico puede resultar ajeno para quienes no se han relacionado con la actividad, razón por la cual en este breve apartado se hacen explícitos los contenidos del documento central, a la espera de situar en su justo contexto los aspectos que lo componen. El desarrollo de cualquier tipo de montaje museográfico requiere el abordaje de distintas materias, sin embargo, teniendo en cuenta que el proyecto CiNemotecnia de Cali no cuenta con una colección objeto de curaduría, su contenido variará respecto de otros ejercicios que sí las consideran. En este sentido, el producto que se desprende del proyecto, se presentará en formato digital a través de un multimedio, y no mediante una exposición en el sentido estricto.

Originalmente, toda propuesta museográfica debe considerar un apartado denominado "Guión temático" en el cual se esboza una presentación del proyecto, los antecedentes de la exposición, es decir, otros montajes similares al que ésta presenta, la justificación que respalda el desarrollo de la misma, los núcleos temáticos, o sea, los temas y los subtemas que se expondrán y una descripción general de la colección objeto de la curaduría. Aunque los produc-

* Danilo Duarte es politólogo y Miembro de los Seminarios de Estética y Cultura del Departamento de Humanidades de la Universidad Icesi. Una de sus áreas de interés académico está centrada en realizar proyectos de museografía comunitaria. 
tos del proyecto complementarán la narrativa de uno de los núcleos temáticos de "Caliwood. Museo de la Cinematografía", la investigación dista de tener una colección precisa sobre la cual realizar la curaduría y su descripción general, razón por la que se optó por presentar un abordaje contextual de los aparatos ópticos comúnmente vinculados al origen del cine, el cual se detallará en el guión científico. Así, el lector podrá notar la ausencia de ese numeral en este apartado. El "Guión científico" corresponde a un capítulo del documento en donde se consigna la investigación documental realizada en torno a los temas y subtemas seleccionados, este es el cuerpo académico del texto puesto que en él se hacen explícitos los hallazgos y tensiones que presenta el tema tratado. A partir de los contenidos de este guión, se elabora el cedulario y el guión curatorial de la exposición, en el que se presentan de manera esquemática los elementos cruciales de la temática abordada. Así, el guión científico debería estar presente en todo proyecto museográfico, en tanto que se constituye en el punto de partida de los contenidos de la exposición; en "CiNemotecnia..." este guión ocupa la mayor extensión en el texto. La "Lista de obra" es una sección en la que se individualizan las piezas que se exhibirán; por lo general, dicho registro implica consignar el nombre de la pieza, el autor, las características físicas, el estado de conservación, su descripción, entre otros aspectos. En el documento que se presenta, esta unidad se encuentra ausente por las razones señaladas con anterioridad, es decir, no hay objetos sobre los cuales se haya realizado la investigación, sino que ésta se ha efectuado sobre los contextos que han propiciado la emergencia de los mismos. El "Cedulario de la exposición" corresponde a un módulo en el cual se establecen los apoyos textuales que complementan la gramática objetual de la exposición, incluyen textos introductorios a la exposición en general (cédulas introductorias), cédulas temáticas que contextualizan al visitante en los temas en cuestión, cédulas de objetos, en donde se apuntan las características físicas de los expósitos y otros tipos de señaléticas como los pies de fotos. En este documento, el lector notará la ausencia de dicha unidad, puesto que se ha optado por integrar los textos en la siguiente unidad que conforma el proyecto museográfico, a saber, el "Guión curatorial”. El guión curatorial es un esquema sintético en el cual se vierten los contenidos de las unidades precedentes, de tal manera que se tiene una vista panorámica de la exposición: cuáles serán los temas a tratar, sus objetivos, las cédulas que acompañan a los objetos expuestos, los objetos mismos, los apoyos museográficos y otras especificaciones técnicas con las cuales realizar el montaje. La particularidad del guión curatorial en este proyecto radica en que antes que nutrir a un montaje convencional, contribuirá al diseño de un dispositivo interactivo en donde, por ejemplo, el cedulario servirá como el texto que acompañe a la imagen del recurso. El "Levantamiento fotográfico de las salas" y la elaboración de "Planos" son las actividades previas necesarias para proyectar el mobiliario museográfico en el espacio asignado (bases, vitrinas, ménsulas, iluminación, etc.), la ubicación de los objetos, de los textos y demás apoyos gráficos. Este proyecto no considera la intervención de un espacio específico, puesto que los multimedios a diseñar pueden ubicarse conforme a las necesidades del museo, en este caso, la sala arqueología del cine o en otro es- 
pacio en donde se refuerce el contenido de la misma.

Hay una crítica de la que podría ser objeto el trabajo que se presenta a continuación que tiene que ver con la ausencia de un debate en torno al fenómeno cinematográfico, nada más lejos de la verdad puesto que se ha planteado una tensión entre considerar a los dispositivos ópticos de fines del XVIII y comienzos del XIX como una suerte de experiencia cinematográfica inacabada, pensamiento que acarrea una serie de dificultades cuando se intenta indagar en la especificidad histórica de tales artefactos. Es cierto que dichas tensiones no han visto la luz bajo el alero de esta investigación, por lo que este proyecto puede considerarse como una caja de resonancia que plantea una tensión en un campo que precisa de otras miradas para enriquecer el debate. En adición, más allá de la estirpe descriptiva de este documento hay que sopesarlo en su justa medida, es decir a tono con los objetivos del trabajo en museos, además, este proyecto se puede enmarcar dentro del llamado que realiza la profesora Juana Suárez, de la Universidad de Kentucky, quien aboga por los trabajos de curaduría que compilen y difundan los distintos aspectos del cine colombiano que, con todas sus limitantes, "merece ser estudiado". 


\section{GUIÓN TEMÁTICO}

\section{Presentación del proyecto}

En el marco de la Convocatoria Interna de la Universidad Icesi, se ha venido adelantando durante el primer semestre de 2013 (2013-I) el proyecto de investigación CiNemotecnia de Cali, una iniciativa que, a través de la generación de diversas estrategias, busca traer a la memoria distintos aspectos que componen la historia del cine en la ciudad. Recurriendo a las tecnologías de la información y la comunicación, el proyecto se ha propuesto esclarecer los contextos y los mecanismos que dan vida a los denominados dispositivos ópticos comúnmente asociados con la génesis del cinematógrafo. Asimismo, a través de la sistematización y registro de algunos testimonios, se espera dar a conocer algunos de los espacios (teatros) en los que se proyectó el cine en Cali. Esta iniciativa tiene como socio estratégico a "Caliwood. Museo de la Cinematografía", por lo que se espera que parte de los productos generados por "CiNemotecnia..." vayan a dar a las salas de este museo, de tal manera que puedan fortalecer la narrativa museográfica que allí se presenta.

\section{Antecedentes}

El vínculo entre el cine y la preservación, es decir, la ciencia que se dedica a la conservación y el manejo de las colecciones cinematográficas - una de las tres funciones que actualmente dominan la práctica museológica, junto a la investigación y la comunicación - puede encontrarse en los intentos por salvaguardar al cine silente, llevado a la sombra por la aparición del cine sonoro en la década de los veinte del siglo XX, pudiéndose observar de manera temprana esfuerzos por conservar en archivos y cinematecas esos registros. Es el caso de la Colección Nacional de Cinematografía en Londres (1913), las cinematecas nacionales en Estocolmo (1933), Berlín (1934), París (1938), la Cinemateca del Museo de Arte Moderno de Nueva York (1935) y la Filmoteca Colombiana (1954). Este breve listado devela la ausencia de una relación explícita entre el cine y los museos, puesto que es la figura de los archivos la que la domina ${ }^{1}$; a pesar de ello se encuentra en la Filmoteca del Museo de Arte Moderno de Nueva York uno de los intentos más fructíferos por establecer este lazo, a través de un esfuerzo por generar conciencia acerca de la tradición histórica del nuevo arte cinematográfico, así como por ilustrar dicha historia mediante sus acervos en un contexto educativo. Si a ello se suman los estudios realizados en torno a la figura de D.W Griffith - el padre del cine

${ }^{1}$ Si bien los itinerarios del cine y los museos se han intersectado en algunos momentos, no ha habido una estrecha coexistencia entre ellos a lo largo de sus historias: si la del primero es breve, la de los museos dedicados a la cinematografía es aun más resumida. 
moderno - vemos que dichas actividades constituyen el fondo de la actividad museológica, la investigación, la preservación de los objetos y su crítica a través de la exposición. La distinción fundamental entre unos y otros, entre archivos en su versión de filmotecas o cinematecas y un museo dedicado a este arte, radica en que este último resguarda principalmente los artefactos que en algún sentido han mantenido una relación con el cine en tanto que práctica socio-cultural, en tanto que las primeras persiguen la conservación de originales, copias y negativos de películas así como su difusión mediante su proyección; aunque es preciso señalar que en la actualidad resulta difícil identificar diferencias funcionales claras entre estas instituciones, ya que ambas comparten labores museales orientadas a la preservación, investigación y comunicación de los materiales en salvaguarda.

El cine permaneció lejos de la mirada pública del museo dado su carácter "impuro" desde el punto de vista artístico, esto es, la falta de autonomía en el campo representacional; la pureza en el arte de la modernidad tiene que ver con el repliegue de los métodos propios de las disciplinas sobre sí mismas, de tal manera que se puedan conocer sus efectos y garantizar su calidad e independencia: el arte es el tema del arte. Y aunque el cine podría replegarse sobre sí mismo, jamás podrá hacerlo absolutamente, puesto que precisa de la inclusión de elementos "exteriores" a él para componerse tanto narrativa como técnicamente. De esta manera, el cine es impuro en la medida que recurre a otras disciplinas, entre ellas las artísticas, para su propia consolidación. Junto a este elemento de impureza, hay que agregar otro más para explicar las razones de la inclusión tardía del cine en la agenda del museo: la cinefilia, el amor por el cine se ha cultivado al alero de los teatros de los sueños, lugares clandestinos y colectivos, para doctos y legos, en donde se realizaba una lectura a la vez popular y culta, por lo que se consideró inútil "museizar" el cine. No obstante, a partir del centenario de la primera proyección pública del cinematógrafo Lumière, de eso ya cerca de veinte años, el advenimiento de las tecnologías de la imagen y del sonido y la consecutiva llegada del "cine en su casa", la paulatina desaparición o transformación de los antiguos teatros en multisalas, la actividad turística asociada a las locaciones en las que fueron filmadas cintas paradigmáticas, la fascinación de algún coleccionista por asir parte de la historia del cine o el interés de una administración nacional, regional o local por salvaguardar los distintos aspectos de este arte, entre muchos otros aspectos, han contribuido a la fundación de museos dedicados al cine en los cinco continentes, sin mencionar los museos virtuales y las colecciones privadas creadas a este propósito.

Heredera directa del primer archivo audiovisual en el país - Filmoteca Colombiana, más tarde conocida como Cinemateca Colombiana - la Fundación Patrimonio Fílmico Colombiano (FPFC) fomenta la producción de obras audiovisuales, publicaciones y exposiciones que den cuenta del devenir de la historia del cine nacional, asimismo, es el ente público que no solo custodia, restaura y preserva los primeros registros cinematográficos colombianos, sino que también salvaguarda casetes de video y registros sonoros en distintos formatos. En cuanto 
al tema que nos atañe, las temáticas museográficas, la FPFC con el apoyo de la Dirección de Cinematografía del Ministerio de Cultura, del Museo Nacional de Colombia, del Fondo para el Desarrollo Cinematográfico, del Fondo Mixto Proimágenes en Movimiento y de la Fundación Cine Cultura realizó entre los años 2008 y 2009 la exposición "Luces y Sombras", un montaje a través del cual se buscó dar a conocer algunos de los principios y descubrimientos realizados en torno al cine, las diversas etapas de su desarrollo y los principios ópticos que antecedieron a su descubrimiento, ejemplificados mediante réplicas de los aparatos precinematográficos.

Por su lado, el Museo Nacional de Colombia, en asocio con FPFC, montó entre el 18 de octubre de 2007 y el 28 de enero de 2008 la exposición “iAcción! Cine en Colombia” la cual coincidió con varias efemérides relacionadas con el desarrollo del cine en el país: 110 años del primer espectáculo cinematográfico, 70 años del primer registro de cine sonoro y parlante, etc. A través de imágenes, documentos, fotografías y otros objetos, el montaje procuró que los visitantes se acercaran a los distintos momentos en los que se ha forjado el cine nacional, la relación de éste con la sociedad colombiana y su contribución al afianzamiento de la idea de nación. Mediante el tratamiento de seis núcleos temáticos, entre los que cabe destacar El cinematógrafo en Colombia: redescubrimiento y conquista de un país (1897-1915), El cine silente o la Colombia idealizada (1916-1937), El poder de la ideas (1938-1959), ¿Los años dorados? (1978-1996) y Un gran supermercado audiovisual (1997-2006), la exposición pretendió fijar en el imaginario colectivo la comprensión del séptimo arte como un hecho social.

En el último año (2012), la Alcaldía Mayor de Bogotá a través de la Cinemateca Distrital y en asocio con la FPFC llevó a cabo la exposición "Arqueología del cine y periodo silente de la cinematografía colombiana" un montaje que recurre a la construcción de réplicas de tamaño natural de distintos juegos ópticos que antecedieron la emergencia del cine, asimismo, a través de cédulas y paneles explicativos se buscó la comprensión de la mecánica fisiológica que permite la fusión de imágenes que da vida a la proyección cinematográfica. De manera paralela a la exposición, una serie de conferencias y talleres complementaron la tarea propuesta para el montaje, a saber, acercar a los espectadores al conocimiento y goce del patrimonio audiovisual nacional.

A principios de 2011 vio la luz en la capital del Valle del Cauca el primer museo dedicado a la cinematografía en Colombia; "Caliwood. Museo de la Cinematografía” que, junto con conservar los proyectores usados en distintos teatros del país (Armenia, Bogotá, Buga, Cali, Duitama, Génova, Ipiales, La Cruz, Palmira, Pasto, Pereira, Pueblo Tapao y Restrepo), resguarda otros objetos asociados al cine nacional como filmadoras manuales, cámaras, cortadoras y empalmadoras de acetatos, avisos, películas, carteles, proyectores de uso doméstico, ampliadoras de fotos, etc. La exposición permanente del museo podría dividirse en cinco núcleos temáticos: i) la arqueología del cine, ii) los proyectores de cine comercial en Colombia, iii) 
los proyectores caseros, iv) las cámaras filmadoras y fotográficas y v) los afiches de la producción fílmica nacional. El origen del museo se encuentra en la pasión coleccionista de su director que, tal como señala en su portal web a propósito de otra de sus aficiones, por pura casualidad se topó con los proyectores usados antiguamente en el Teatro Jorge Isaacs, hecho que marcó su inclinación por el interés en el séptimo arte colombiano.

Los grandes museos dedicados al cine como el Museo Nazionale del Cinema en Torino, Italia, el Film Museum Potsdam, en Alemania, el Museu del Cinema en Girona, España, el Australian Museum of Motion Pictures \& Television en Leederville, entre muchos otros, resguardan colecciones sin iguales con las cuales representan el devenir de la historia pre-cinematográfica del séptimo arte. Baste con mencionar que el Museo Nazionale del Cinema cuenta con uno de los acervos más importantes a nivel mundial en lo que se refiere a los aparatos ópticos de finales del siglo XVIII y principios del XIX: zoótropos, tuti li mundi o mundos nuevos, taumatropos, fenaquistiscopios, entre otros, los que hacen parte de su exposición permanente. Lo mismo ocurre con el Museu del Cinema en Girona, creado a partir de la colección de Tomás Mallol, cuya colección está constituida en gran parte por aparatos provenientes de la segunda mitad del siglo XVIII hasta el primer tercio del siglo XX; con base en dicho acervo, el museo dedica parte de su labor educativa a la difusión de los mecanismos que configuraron la pre-historia del cine y los primeros años de su existencia. En Colombia, aparte de las instituciones señaladas, FPFC y Caliwood, son escasos los espacios que se han consagrado a la comunicación de la pre-historia del cine, de ahí que un proyecto como el planteado resulte significativo al momento en que pretende, a través de un trabajo curatorial que integra a las TIC's, fortalecer la narrativa museográfica del núcleo temático de un museo que precisamente intenta indagar en las honduras de esa pre-historia.

\section{Justificación}

Somos testigos de una era en la que la imagen es todo, hemos llegado al momento que la escritora Susan Sontag profetizara a mediados de los setenta, aquél en el que la imagen se ha convertido en la realidad misma. Esta profusión de la producción icónica impide al hombre del presente establecer una relación con el pasado puesto que lo actual es todo y en cualquier caso, aunque éste pudiera fijar su mirada en el hecho pretérito, su relación no es más que referencial, maquillada y mediada por la imagen vigente. Aunque en las sociedades del hoy abundan los museos del mañana y la onda retro y el revival dominan las escenas arquitectónicas y las de la moda, las distintas comunidades que las componen padecen de una amnesia sin parangón - sufren la enfermedad del insomnio diría García Márquez - producto de la intervención del mercado y los medios de comunicación, quienes han abrevado notoriamente al olvido a través de la sobreinformación, notable paradoja. Para el filósofo Diego Lizarazo, la sociedad en la que nos desenvolvemos es una sociedad aséptica, límpida de toda 
remembranza, ya que las mercancías producidas en su interior, desechables, previamente obsoletas y diseñadas para su destrucción, una vez deshechas, higienizan al cuerpo del recuerdo de la experiencia vivida. En este marco, en donde el mar de imágenes ahoga la mirada de los incautos es precisa una pausa para la deglución del bombardeo icónico, ya que es en ese momento en donde el pasado, sea reciente o no, puede iluminar el presente ya que sólo en ese momento aquél forma parte de éste.

"Parecía como en el cine", "era como en las películas", la vorágine iconográfica ha devorado también las imágenes producidas por el cine y las ha fusionado con las de la "realidad", de ahí que no resulte extraño escuchar la explicación de un hecho cotidiano a partir del recurso de las imágenes artificiales proyectadas en las multisalas. El torrente de tecnologías visuales empleadas en el cine de vanguardia - tecnológica - hace caer en el olvido aquellas técnicas centenarias como la del estereoscopio que en su momento sorprendieron la mirada del público moderno, así como hoy se asalta la imaginación del "público 3D" en el séptimo arte. El cine actual le debe mucho a los dispositivos "pre-cinematográficos", acusa el realizador Pablo Gotor no sin razón, puesto que es gracias a éstos y a la demostración a través de ellos que era necesaria la secuenciación de 12 fotogramas por segundo para obtener una imagen en movimiento relativamente fluida, el principio que guía hoy la animación stop-motion, la pixilación, o los cristales de la linterna mágica que bien podrían haber inspirado la técnica de la animación de recortes o cutout animation, o la misma técnica del visor binocular que tempranamente dio origen a las vistas en tres dimensiones, y que en la actualidad, llega a las casas de una creciente mayoría mediante televisores especializados.

Pues bien, en este aluvión icónico al cual abrevamos también los sujetos mediante la saturación de la nube, a estas alturas una de tipo cúmulo-nimbo, se hace necesario encontrar un claro en el tupido bosque iconográfico donde detenernos y reflexionar acerca de los contextos y los aparatos que comúnmente se han asociado a los orígenes del cine. Teniendo como institución asociada a "Caliwood. Museo de la Cinematografía", los resultados de este proyecto, o sea, un guión museológico y una maqueta museográfica-multimedia, complementarán la narrativa que presenta el museo en su núcleo, "La arqueología del cine", de tal manera que se fortalecerá el mensaje que éste emite facilitando la transmisión de su contenido.

\section{Objetivo General}

Contribuir a la difusión de la historia del arte cinematográfico en su faceta arqueológica, comenzando con la creación de los aparatos ópticos que antecedieron su creación, hasta bien entrada la década de los sesenta del siglo XX cuando cobran relevancia los relatos arquitectónicos y testimoniales de su circulación en Cali. 


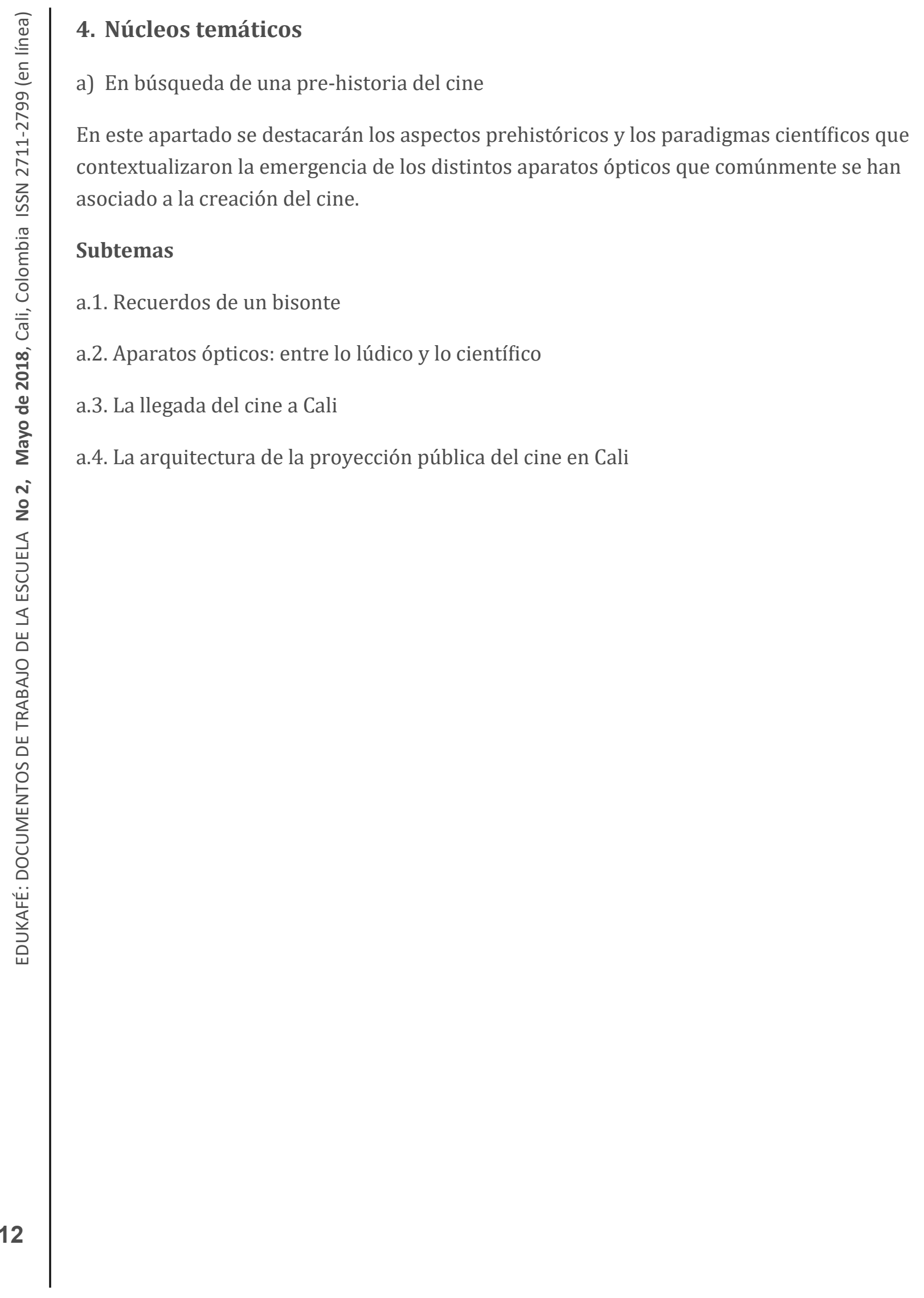




\section{GUIÓN CIENTÍFICo}

\section{Presentación}

Conocer los antecedentes previos al advenimiento del cinematógrafo a fines del siglo XIX, resulta fundamental para comprender el contexto en el que ve la luz este aparato. Su creación es tributaria de un entorno científico en donde el interés por develar la mecánica del cuerpo humano resulta la piedra miliar para el desarrollo del llamado "arte del siglo XX". En este sentido, el guión que se desarrolla a continuación presenta los aspectos que, aunque concebidos para otros fines distintos al entretenimiento como es el cine, no pueden dejar de conocerse en la medida que sin ellos el surgimiento del Séptimo arte hubiera adquirido otros ribetes.

\section{En búsqueda de una pre-historia del cine}

Objetivos

Destacar los albores del "comportamiento simbólico" del sujeto Prehistórico, así como sus manifestaciones culturales que actualmente se asocian con la imagen en movimiento.

Señalar los paradigmas científicos que contextualizaron la emergencia de los distintos aparatos ópticos que comúnmente se han asociado con la creación del cine.

Resaltar la llegada del cine a la ciudad de Cali y los hitos que le han granjeado un lugar al Departamento en la historia de la cinematografía en Colombia

\section{Subtemas}

\subsection{Recuerdos de un bisonte}

Un aspecto que marca la evolución del hombre prehistórico es el momento en que comienza a manifestar un "comportamiento moderno", es decir, cuando despliega ciertas habilidades para el empleo de un lenguaje avanzado y para expresarse a través de elaboraciones simbólicas complejas como el arte, por ejemplo. Precisamente, este "comportamiento simbólico" es el que da pie para pensar al arte paleolítico como un medio para transmitir mensajes naturalistas y alegóricos; naturalista en la medida en que las pinturas rupestres dejan un registro más o menos preciso del entorno ambiental prehistórico - de su fauna preferentemente

- y alegórico, en el sentido de que pueden simbolizar la identificación del hombre primitivo 
con las bestias que lo rodearon, como podría ser el caso del león cavernario. Las pinturas rupestres y las figurillas paleolíticas de 40.000 años de antigüedad bien podrían ser las manifestaciones más tempranas de la humanidad del hombre, porque es en ese momento en el que éste se abstrae del mundo exterior y da paso a su captura y a su inscripción en trozos de hueso, en rocas, en las cuevas, en las salientes de los acantilados y en los barrancos; en este contexto pretérito, el protohombre moderno se adapta a su medio, lo registra y lo comunica a través de la figuración, una forma de comunicación entre esos humanos ancestrales y entre ellos y el futuro, el hoy presente que a través de ella evoca un pasado desvanecido por el tiempo. Hallazgos arqueológicos fortuitos del despertar pictórico del hombre primitivo, ubican en su quehacer esfuerzos de composición expresiva en la que intervienen aspectos narrativos - mamuts pastando en una llanura olvidada y luego en alerta frente a una eventual amenaza - y de movimiento - la desfragmentación de la marcha de un felino prehistórico que inicia la caza - pudiéndose afirmar de su integración una intención final que consiste en describir una historia a través de una secuencia definida de movimientos. Aunque las pinturas que imprimen dinamismo en sus trazos hasta el momento no hacen parte de la generalidad de los hallazgos en las artes del paleolítico, no es menos cierto que la totalidad de estas creaciones, cuya temporalidad abarca desde el 40.000 a.C hasta el 2.000 a.C, buscaron representar no sólo la fauna y el medio circundante sino también la interacción habitual entre las comunidades y su entorno a través de motivos como las figuras humanas, el pastoreo del ganado, la caza de búfalos, las manadas de caballos salvajez y de gamuzas, incluso actividades subacuáticas.

Estos primitivos ensayos de relatos ¿pueden asociarse a lo que hoy entendemos como cine? Para algunos la coincidencia de las variables narrativa y movimiento podría representar el principio de la animación cinematográfica ya que motivos dinámicos tales como "animales en acción o escenas de caza" bien pueden "crear una historia en la mente del espectador, como ocurre en las películas". Para otros, en cambio, el establecimiento de estas relaciones es un despropósito ya que la cinematografía vendría a ser un producto exclusivo de la ciencia, la técnica y los descubrimientos realizados durante el siglo XIX. Es indiscutible que para referenciar al cine actual se tuvo que sortear procesos técnicos elementales como la sensibilidad de la película, la longitud suficiente de ella misma y el sistema de arrastre que le permitiera avanzar de manera intermitente pero continua, pero también en la esencia de ese cine se encuentra presente la estructuración de una historia, misma sobre la que luego se volcará la mirada curiosa del observador.

Con lo anterior, no resultaría aventurado asegurar que el hecho narrativo es consustancial al hombre, siendo un acto que conforme acompaña la evolución de éste perfeccionará su técnica y los lugares de su inscripción, tal como queda en evidencia cuando se conocen los distintos soportes utilizados al momento de contar una historia que van desde estelas, columnas, lienzos hasta códices y otros objetos mobiliarios. De estos últimos un vaso de cerámica del 
5200 años de antigüedad (3000 a.C) encontrado en Irán; su decoración exterior narra en una secuencia de 9 instantes - ¿o fotogramas? - el momento en que una cabra salvaje salta sobre un árbol para comer de sus hojas; lo mismo con una estela egipcia del 4000 a.C, que detalla las innumerables posiciones de combate entre dos luchadores, si se seccionara cada una de dichas posturas y esos fragmentos se ordenaran como flipbook el movimiento reconstruido daría cuenta de un feroz enfrentamiento entre dos gladiadores de piedra o bien la columna de Marco Aurelio (180 d.C) que en sus 32 metros de alto por 3,7 de diámetro narra gráficamente, en veinte espirales, los triunfos del emperador romano sobre los pueblos germanos. En América, en tanto, un ejemplo de narrativa histórica vendría a ser los códices mesoamericanos. Los códices son libros manuscritos pictográficos - es decir, escritos por medio de dibujos - realizados por los indígenas de México y Centro América (mayas, aztecas, mixtecos, zapotecas, otomíes y purépechas, entre otros) desde antes de la llegada de los españoles hasta fines del siglo XVII, narrándose en ellos aspectos económicos, sociales, históricos, científicos y religiosos; ya que para su elaboración se utilizaron principalmente fibras vegetales, sólo algunos ejemplares han alcanzado nuestros días, encontrándose en las bibliotecas más importantes de Europa y de México. En Asia, particularmente en China y Japón, por siglos se practicó un arte pictórico monumental que buscó unir la narrativa y el movimiento con el propósito de fijar en la mente de quienes la observaran una suerte de, lo que sería hoy, tira cinética de gran dinámica visual. Los pergaminos narrativos japoneses creado entre el siglo XI y el XVI (emakimonos) son pinturas horizontales cuyas dimensiones fluctúan entre los $30 \mathrm{~cm}$. de alto y los nueve o doce metros de largo; en ellas se describen mediante el uso de pigmentos y de textos batallas, cuentos populares e historias del mundo sobrenatural, llegando a utilizarse hasta tres pergaminos de papel de seda para narrar una historia completa. El pergamino de paisaje chino (Chinese Landscape Scroll), en cambio, supera con creces las dimensiones de su pariente nipón llegando a compararse con los panoramas decimonónicos ya que sobrepasan los treinta metros de longitud. Estas pinturas, consideradas hasta hoy en día una de las manifestaciones más elevadas del arte de ese país, surgieron entre los años 907 y 1127 época reconocida como "la gran edad del paisaje chino". De vuelta en el viejo mundo, en plena Edad Media, el tapiz de Bayeux (1064-1066) viene a ser la pieza más representativa de un intento narrativo en Europa; de lino bordado y lana, relata la historia de la conquista de Inglaterra a manos de Guillermo de Normandía, su futuro rey. De dimensiones inconmensurables - setenta metros de largo - bien podría disputar junto al Chinese Landscape Scroll el rótulo de predecesor del invento de Robert Barker.

¿Cómo asociarles a los lienzos de la Edad Media y del Lejano Oriente estáticos e inalterables, la temporalidad necesaria "para que la experiencia humana distinga el desarrollo de una acción, que es a final de cuentas la condición básica de toda narratividad?" Las alternativas son dos, una opción gráfica y otra relacionada con la simultaneidad. Mientras que la primera hace referencia al uso de convencionalismos plásticos que representan el movimiento de los objetos, tales como las líneas cinéticas que dan cuenta de la trayectoria que éstos recorren, 
la segunda tiene relación con el espacio mismo del lienzo que impone "a la imagen un orden y una jerarquización de elementos a lo largo de su eje horizontal". Este último recurso es el que convierte a los trabajos referenciados en efectivos medios visuales "no solamente dedicados a la recreación de espacios y escenas sino que también destinados a la comunicación social de eventos tal como el tapiz de Bayeux y el triunfo de Guillermo el conquistador.

Ciertamente, los modelos reseñados - desde el arte paleolítico al Medioevo, pasando por los códices prehispánicos - están lejos de ser considerados como una película propiamente tal, sin embargo, ha quedado en claro que la humanidad desde sus comienzos ha intentado relatar y transmitir sus experiencias a través historias mediante la utilización de imágenes y cada una de las referencias mencionadas aquí da cuenta de ello. Estas imágenes pretéritas exigen al observador del nuevo milenio empujar su imaginación para poder "ver" como las cabras salvajes saltan y los bisontes y mamuts deambulan por llanuras antiguas, para poder "escuchar" las plegarías mexicas y el caudal trepidante de los ríos que bajan de las lejanas alturas del Extremo Oriente.

\subsection{Aparatos ópticos: entre lo lúdico y lo científico}

Los dispositivos ópticos y mecánicos asociados comúnmente a los orígenes del cine son protagonistas de una historia que desborda la temporalidad de su relato decimonónico, coincidiendo con uno que se inclina a considerarlos producto de los paradigmas científicos que guiaron en su momento la reflexión sobre el "mundo". Una historia ininterrumpida, dominante e integradora podría esbozar y organizar un modelo explicativo de un fenómeno, pero es insuficiente para dar cuenta de los saltos y las discontinuidades propios de todo hecho historiográfico como ocurre en los casos del cine, la fotografía y la cuestión del observador. Se afirma que con el surgimiento de la fotografía y el cine, se culminó un proceso de desarrollo tecnológico inaugurado por la cámara oscura en el siglo XVI; que la perspectiva renacentista y la fotografía buscaron al mismo tiempo el equivalente objetivo de la "visión natural, sin embargo, con ello se obvian los particulares parámetros de sus especificidades históricas, de tal manera que se les subsume en una línea de continuidad invisibilizadora.

El principio óptico de la cámara oscura es conocido al menos desde 2.200 años - aunque investigaciones recientes apuestan por sostener la teoría de una "paleo cámara" - asociándosele desde un principio con la génesis de la fotografía y el cine, empero se le pasa por alto como aparato construido históricamente, o sea, como artilugio inserto en una trama más amplia y densa de conocimiento. Adjudicada al filósofo italiano Giovanni Battista della Porta quien, en su libro Magia Naturalis (1558), hace referencia a las experiencias de reflexión de la luz y el uso de espejos cóncavos para mejorar la resolución de la imagen provista por la cámara; la trascendencia del erudito renacentista radica en el modo en que a través de sus 
ensayos inauguró una nueva "organización del saber y del ver" que tuvo en el principio de la observación la base para la decodificación de las verdades del mundo. Los sentidos en el hombre del Renacimiento no resultaban recursos fiables para dar cuenta del medio circundante, en especial cuando los principios dominantes de la época se encontraban determinados por el carácter científico-matemático de las leyes dictadas por la perspectiva geométrica y se tenía a la naturaleza "como maestra y modelo estético". En este contexto, y hasta finales del siglo XVIII, la cámara oscura instituyó un régimen basado en principios estructurales y ópticos que abrevaron a su cimentación como "metáfora filosófica" en donde el sujeto, en una suerte de operación "metafísica de la interioridad", se abstraía del mundo para normar y "purificar" su relación con éste; como arquetipo "de la ciencia de la óptica física" que descorporeizó la visión, mutilándola del cuerpo físico del observador y suplantándola por las relaciones que estableció en su lugar la habitación oscura con el mundo exterior y como artificio técnico utilizado en una serie de actividades culturales cristalizado en la linterna mágica, ingenio que logró apoderarse de la estructura interna de la cámara. Para el historiador del arte Jonathan Crary, si bien la cámara fotográfica y la cámara oscura pueden guardar principios estructurales similares, son objetos sociales diferentes ya que son propios de dos órdenes distinto tanto de la representación y del observador como de la relación de éste con "lo visible", de ahí que sugiere que esta última debería ser liberada de la "lógica evolucionista y del determinismo tecnológico" que la apunta como hecho catalizador de un relato que converge con la génesis de la fotografía. Por el contrario, en el caso que se mantenga atada a este relato dominante, se estarían subsumiendo los paradigmas a través de los cuales se ha construido históricamente la visión y el observador en una "tradición occidental monolítica" que no contribuye a comprender el devenir de los medios visuales. Baste con señalar que a "principios del siglo XIX, la cámara oscura ya no es sinónimo de producción de certezas ni poseedora de verdades ópticas y que la cámara fotográfica se instaló en un orden y práctica totalmente diferente respecto al status quo que dominó la escena visual entre fines del XVI y las postrimerías del XVIII.

La reorganización del conocimiento que tuvo lugar a principios del siglo XIX se instaló en oposición a la concepción de la habitación oscura, cuyo principal postulado apuntaba - como se ha visto - a establecer una relación entre interior-exterior. El advenimiento de nuevas concepciones que desestabilizaron al paradigma dominante, halló su razón de ser en las conclusiones de estudios realizados de manera independiente, pero que en conjunto abrevaron a la cimentación de un nuevo observador: el dramaturgo y científico alemán Johann Wolfgang von Goethe en su libro Teoría del colores (1810) dio cuenta que el fenómeno del color es más propio de la fisiología humana que un correlato de la cámara oscura, con ello puso en escena a un "observador fisiológico" capaz de producir de manera autónoma su propia experiencia visual; el francés Maine de Biran, psicólogo y filósofo, sostuvo que el cuerpo era la condición previa para toda percepción visual, por lo tanto músculos y esfuerzo físico eran inseparables de ésta, que la percepción del color estaba condicionado por la fatiga del 
cuerpo y que el cansancio afectaba de manera decidida a la percepción. Ambos concibieron a la observación subjetiva, aquella que ocurre en los órganos del sujeto, más que un ejercicio introspectivo como un campo de estudio en donde el observador y lo observado fueron los objetos mismos de la investigación, de la regulación y de la disciplina. Arthur Schopenhauer, filósofo, compatriota de Goethe, recalcó la naturaleza subjetiva de la visión al asegurar que en la constitución fisiológica del individuo era en donde acontecía la formación de las representaciones, era el sujeto al mismo tiempo el lugar y el productor de la conciencia de la imagen, de ahí que el fenómeno del color podía ser abordado por una teoría exclusivamente fisiológica. Goethe y Schopenhauer coincidieron en señalar que la percepción del mundo y su representación se desarrolla en el interior de la corporalidad del sujeto y que la existencia de formas y densidades eran la consecuencia directa de la intervención de sus órganos sensoriales; esta denominada visión subjetiva fue la que dotó al observador del siglo XIX de una autonomía perceptiva y de los recursos para transformarse "en un sujeto de nuevos saberes y técnicas de poder".

En este contexto surge la fisiología como ciencia, un campo de estudios cuya reflexión en torno al ojo y al proceso de visión supuso un giro epistemológico que tuvo al cuerpo del individuo como el nuevo lugar en donde se emplazó "el poder y la verdad" y a este órgano como campo de información estadística. Aunque fenómenos visuales como las postimágenes eran desde antes conocidas, no fue hasta comienzos del siglo XIX que estas manifestaciones oculares dejan de ser engaños, para pasar a ser "componentes irreductibles de la visión" y, por tanto, verdades ópticas. Esta objetividad emanada de la observación subjetiva, subjetividad corpórea o visión subjetiva implicó la incorporación de dos aspectos para comprender a cabalidad el fenómeno visual: la introducción de la variable tiempo como elemento obligado de la observación y la consideración de la postimagen como la demostración práctica de que la percepción sensorial puede prescindir de referentes externos que la catalicen, lo que refuerza la concepción de la visión autónoma como experiencia sucedida en el interior del sujeto. La subjetividad autónoma, la ausencia en las sensaciones visuales de un referente externo, puso en crisis el sistema de significados y de representaciones a partir del cual se constituía y se aprehendía el mundo, por lo que los fisiólogos de las décadas de 1820 y 1830 buscaron una manera de definir un marco científico para regularlo y organizarlo: entre otros, el psicólogo y filósofo alemán Johan Friedrich Herbart quien fue uno de los primeros en intentar "cuantificar la dinámica de la experiencia cognitiva" y el fisiólogo y anatomista checo Jan Purkinje, quien realizó experimentos para determinar cuánto tiempo la postimagen permanecía visible en el ojo, cuánto tiempo tardaba la pupila en dilatarse y contraerse y cuánto tardaba este órgano en fatigarse. La investigación de las postimagenes llevó a la creación de una serie de aparatos ópticos utilizados en un primer momento para su investigación pero que rápidamente se transformaron en efectivos medios de entretenimiento para las masas. El hecho de que el fenómeno de la percepción no fuera inmediato y de que existiera "una disyuntiva entre ojo y objeto" sugirió la existencia de una combinación de sensacio- 
nes visuales cuando una imagen seguía a otra en una sucesión rápida, por ejemplo, con el taumatropo; esta composición de una nueva vista a partir de una "vieja" secuencia, es en definitiva el hecho que marca la modernidad del observador, ya que el espectador aparentemente pasivo de dichos aparatos, "en virtud de sus capacidades fisiológicas" se convertirá en el productor de "nuevas formas de verosimilitud". Artificios como el zootropo, el fenaquistiscopio - que representan la ilusión de movimiento - y el estereoscopio - aparato que reconcilia la disparidad visual - coinciden en acusar que "la experiencia perceptiva es, a fin de cuentas, una dinámica de aprehensión de diferencias.

Como se ha visto, los dispositivos ópticos de la primera mitad del siglo XIX deben su origen a los intentos científicos por descifrar la mecánica de la visualidad humana la que demostró la existencia de un observador autónomo en comparación con el espectador anterior, mediado y sometido a los designios de la cámara oscura. La contextualización científica de los orígenes de dichos aparatos se debe a que éstos, junto a sus inventores, han sido bien estudiados en el marco de los estudios fílmicos, investigaciones que los han catalogado como pre-cine, como formas imperfectas de éste; no obstante, esta integración conceptual difiere de los postulados de los historiadores de los medios quienes sostienen que dicha unificación constriñe el marco histórico y cultural en el que esos aparatos vieron la luz, por el contrario, su inclusión en una Historia General de la Comunicación Mediada cuyo énfasis se encuentre en la "interioridad" de los artefactos antes que en su "anterioridad" permitiría darle un sentido de "verticalidad y profundidad" al estudio de estos artilugios, evitándose así que cualquiera de estos sea considerado como una síntesis de los que lo precedieron o bien la cumbre a la que se debería llegar con su desarrollo. Son innegables los lazos que atan a los dispositivos pre-cinematográficos y al cinematógrafo - como el fenómeno de la persistencia retiniana por ejemplo - no obstante, hay que considerar a este último antes que como la cima "de una pirámide" como un punto de referencia sin el cual se haría extremadamente complejo organizar sucesos, aparatos, modos de expresión y comprender el conjunto que todos ellos encarnan. Con base en lo anterior, se dará una mirada a los dispositivos ópticos anteriores a la emergencia del cinematógrafo, agrupando sus antecedentes a partir de la selección de una de las dos taxonomías formuladas por el Doctor en Comunicación y Publicidad Rafael Gómez (1998) y por el comunicólogo español Francisco Frutos (1996). Para este último, un marco que contribuye a la ordenación de los artificios decimonónicos es agruparlos en aquellos que recurren a los medios técnicos para la contemplación de la imagen y a los que apelan a los dispositivos ópticos. En el primero de los casos, se refiere a los aparatos mecánicos que se sirvieron de diversas fullerías para asociar una imagen a otra como el diorama o el panorama; que recurrieron a la perspectiva anamórfica y a un mediador para la reconstrucción de la figura, el cilindro anamórfico, o que representaron el movimiento mediante una serie de imágenes vistas en intermitencia a través de ranuras o espejos como el zootropo o el fenaquistiscopio. Para el segundo, en cambio, se privilegia la utilización de juegos de lentes que median la mirada del observador; generalmente ocultos al espectador al interior de las cajas 
mágicas que los contuvieron, la vista era amplificada y presentada en diferentes formatos: monocular y binocular, como los mundonuevos, encontrándose bajo esta categoría otros dispositivos como el estereoscopio. Gómez, por su lado, propone una clasificación con base en el tipo de sistema que genera la vista, agrupando a los ingenios en siete categorías: unos basados en la proyección, que incluye a los aparatos ópticos que recogen la mecánica de funcionamiento de la cámara oscura como es el caso de los distintos tipos de linternas mágicas; otros basados en transparencias, donde el colorido, la profundidad y la luminosidad adquieren gran relevancia, como los panoramas y dioramas; aquellos con base en la permanencia de la visión, como el zootropo, el praxinoscopio y el fenaquistiscopio; otros en función de la movilidad mecánica, que recogían la maquinaria de relojería para mover figuras que realizaban distintos tipos de ejercicio tipo "robots"; los basados en manualidades y trucos en los que se incluyen las sombras chinescas y el taumatropo; otros en secuencias ilustrativas, cuya característica principal es su secuencialidad narrativa muy cercana a lo que hoy se conoce como las viñetas de cómics y, por último, los modelos híbridos que recogen características y mecanismos de unos y otros integrándolos en un nuevo dispositivo como en el caso del Teatro Óptico de Reynaud o el de los panoramas móviles. En estas reflexiones se privilegia la apuesta taxonómica de Frutos, ya que al reunir a los aparatos en dos grandes núcleos se hace más fácil su comprensión y ordenación mental frente a la propuesta elaborada por Gómez que, aunque detallada y precisa, dificulta su inteligibilidad pedagógica.

La inclusión en el ruedo social de ambos tipos de dispositivos - ópticos y mecánicos - y su éxito como medios de entretenimiento masivo, supuso la inauguración de un mercado dedicado a su producción y a la provisión de instantáneas en diversos formatos para éstos: tiras praxinoscópicas y zootrópicas, vistas monoculares y estereoscópicas, discos fenaquistiscópicos, placas de vidrio para linternas, entre muchos otros. La circulación de los aparatos, en principio, por todo Europa llevó a que tuvieran no solo nomenclaturas distintas en cada país, y a su vez en cada nación de dos a tres nombres, sino que también se produjeran aparatos "alternativos" producto de la adulteración del dispositivo original, por lo que resultaba difícil distinguir si el "nuevo" ingenio efectivamente era producto de una investigación fisiológica inédita o si bien era una simple imitación con su respectiva alteración de título. Para evitar la revisión infinita que puede significar examinar los aparatos "originales" y sus remedos, aquí se tratan aquellos dispositivos con los que existe un consenso de que son los precursores de una estirpe óptica-mecánica reconocida. Uno de los dispositivos mecánicos pioneros en la investigación de la postimagen o persistencia retiniana, fue el aparato patentado por el médico británico John Ayrton Paris en 1825; patentado más no inventado puesto que desde la antigüedad se tiene conocimiento que haciendo girar una moneda a cierta velocidad pueden visualizarse al mismo tiempo ambos lados de ella, incluso desde la prehistoria, tal como ha quedado demostrado en el apartado anterior. El taumatropo fue un instrumento científico que devino rápidamente en juguete óptico, éste consistía en un disco de cartón con dos imágenes distintas en cada cara pero relacionadas: un pájaro y una jaula de pájaro, al 
hacerlo girar mediante unos hilos situados a los lados, la visión autónoma del individuo las fusionaba produciendo una tercera impresión estática que era en definitiva "la gracia" del dispositivo, es decir, un pájaro dentro de la jaula. Hay que señalar que este aparato no buscaba crear una ilusión de movimiento ya que como se puede ver, la fusión de las dos imágenes dinámicas creaba una nueva pero fija, al contrario de otros dispositivos contemporáneos que sí perseguían esa ilusión. Diseñados simultáneamente en 1832 por el matemático vienes Simon Ritter Von Stampfer y por el físico belga Joseph Antoine Ferdinand Plateau, el estroboscopio y el fenaquistiscopio, respectivamente, coincidían en su propósito de crear la ilusión de movimiento a partir de un disco giratorio de $25 \mathrm{~cm}$. de diámetro, dividido en dieciséis secciones iguales que contenían la misma cantidad de dibujos que sintetizaban las distintas fases de una secuencia; al hacer rotar la placa frente a un espejo y al visualizar los diseños a través de una rendija de un disco traspuesto al de las imágenes, aspecto técnico incorporado primero por Stampfer que por Plateau, el observador podía ver en actividad los distintos motivos impresos, malabaristas, animales, efectos ópticos, etc. El principio mecanismo de ambos aparatos fue muy popular y prolíficamente "clonado". El fisiólogo Purkinje, por ejemplo, incorporó en un mismo eje el disco con los dibujos y otro disco-espejo con el cual se doto de cierta independencia y comodidad al observador al momento de no tener que depender de su ubicación frente a una superficie reflectante, además la estructura de su ingenio facilitó el cambio del disco de dibujos por otros; como fisiólogo, el checo optó por imprimir en sus discos los latidos del corazón, la circulación de la sangre y diferentes motivos "orgánicos". Otro dispositivo muy popular durante la primera mitad del siglo XIX fue construido por el matemático inglés William George Hornet en 1834: el daedaleum o zoótropo. Este aparato, que recurrió al efecto la persistencia retiniana para su funcionamiento, consistía en un tambor de metal con rendijas que giraba horizontalmente en torno a un eje central montado en un pequeño soporte; su funcionamiento se basaba en unos dibujos distribuidos sobre unas tiras de papel del mismo largo que el diámetro del tambor y que se insertaban en la cara interna a la mitad de su altura; al girar el tambor, el observador que miraba a través de las ranuras podía ver la animación de los dibujos. Como se puede ver, el zoótropo no ofrecía ninguna novedad técnica respecto a los aparatos de Plateau o Stampfer ya que volvía a repetir la ilusión de movimiento de una breve acción, no obstante, tuvo la ventaja de permitir que distintos espectadores observaran la misma secuencia al mismo tiempo ya que se situaban alrededor de la "rueda del diablo".

La aparición de la fotografía introdujo una variante en los artilugios posteriores a los aquí señalados, no obstante, la mecánica postimagen se mantuvo imperturbable en todos ellos siendo este efecto el elemento transversal que los une. El taquiscopio (1885) del fotógrafo e inventor alemán Ottomar Anschütz resultaba un aparato similar al zoótropo con la notable mejora técnica que permitía que una banda longitudinal de instantáneas fotográficas conformará el cuerpo del tambor, cinta sobre la que se hallaban las hendiduras a través de las cuales el observador miraba cómo se desarrollaba el movimiento, asimismo, ya no eran exclusi- 
vamente escenas que se narraban en secuencias horizontales, sino que al poder girarse el tambor en noventa grados se daba vida a nuevas escenas que se desenvolvían verticalmente, como las de ascensos. El tambor taquiscópico dio paso a otra innovación mecánica, el eletrotaquiscopio: un gran disco vertical en cuyos bordes Anschütz colocó una secuencia de veinticuatro fotogramas de diez centímetros cuadrados que hacía pasar frente a una fuente de luz, obteniéndose la animación de los mismos, el destello que las transparencias producían al pasar frente al tubo Geissler que las iluminaba resultan para Frutos el aspecto que más une a este artilugio con el cine, sin embargo, el autor deja en claro que dicho dispositivo por sus características de proyección cíclica sigue siendo un aparato de visión más cercano a los hasta acá revisados que al invento adjudicado a los Lumiere. A fines del siglo XIX, en 1898, Henry William Short presentó un pequeño libro cuyas páginas correspondían a la desfragmentación fotográfica del movimiento de una acción humana, el filoscopio también tuvo una presentación en la que largas tiras de imágenes convergían en un lomo yendo el conjunto de ellas reunidas en una sencilla caja que tenía la función, además de protección, de liberar una a una las páginas mediante un dispositivo de resortes, de esa manera era como se restituía la dinámica visual.

Tomando como referencia el zoótropo, Emile Reynaud, ingeniero, presentó ante la Academia de Ciencias de Francia el praxinoscopio (1877); la mejora técnica de este aparato consistió en que logró eliminar las hendiduras que presentaban el zoótropo y el taquiscopio a través del uso de espejos prismáticos en donde se reflejaban las imágenes. El praxinoscopio de Reynaud compartía la misma estructura física que el invento de Hornet, es decir, un pivote sobre el cual el tambor giraba horizontalmente y una tira de imágenes dispuestas en la cara interna del mismo, a diferencia del zoótropo, en su centro se encontraba una circunferencia menor construida con doce pequeños espejos rectangulares dispuestos de tal forma que reflejaban las figuras de la cinta de imágenes; así, al hacer girar el tambor a través de un sistema de manivela y poleas, el espectador lograba reconstruir la escena ya no mirando sobre los "originales" sino a través de su reflejo. Inspirado en el éxito de ventas del aparato, el francés construyo al año siguiente un dispositivo que concentró la mirada del espectador en una sola imagen central aislándola de aquellas que la precedían y que la sucedían a través de una especie de ventana-escenario a través de la que se accedía a una sola imagen en movimiento, lo denomino praxinoscopio-teatro. Pero quizá el avance más significativo de este inventor fue la creación del teatro óptico, un artilugio de visión colectivo que recurrió a la linterna mágica para proyectar las imágenes. Una linterna ubicada a 1, 70 metros del suelo proyectaba una imagen de fondo estática sobre la que se desarrollaría una acción, la segunda linterna ubicada sobre una mesa y en contravía de la primera dirigía un haz de luz que iluminaba unos fotogramas de diez centímetros cuadrados que manualmente pasaban delante de ella, dicho haz de luz, que atravesaba las imágenes, rebotaba luego en dos espejos lo que permitía que la segunda impresión alcanzara y coincidiera con la proyección de fondo. De esa manera, amplificando el mecanismo técnico del primer praxinoscopio, Reynaud lograba que un arti- 
lugio de uso individual alcanzara dimensiones parateatrales.

Así como los artilugios mecánicos contribuyeron a la conformación de un nuevo observador, el lienzo panoramico ya venía haciendo lo propio desde fines del siglo XVIII. El invento atribuido al pintor irlandés Robert Barker en 1788 favoreció este vuelco ya que, a diferencia de la cámara oscura cuya experiencia visual estaba sometida a la inmovilidad física y atencional del espectador en una habitación sombría y sobre un punto de referencia preciso, la pintura panorámica permitió la movilidad del observador cuando requirió de él girar la cabeza, los ojos y la utilización del cuerpo para recorrer a cabalidad la pintura. El panorama consistía en un cuadro de grandes dimensiones que narraba hechos históricos o que bien plasmaba motivos urbanos, vistas panorámicas, en principio, de las grandes ciudades europeas. Estas obras de siete metros de alto por cuarenta metros de ancho - ciento veinte en circunferencia - se encontraban en el interior de un edificio cilíndrico dentro del cual se ubicaban los espectadores; la instalación de la obra en un espacio de 360 grados implicó que ésta ocupara todo el campo visual del observador favoreciendo de esta manera "la percepción de la tercera dimensión del espacio". En muchos casos la pintura panorámica rotaba delante de los espectadores quienes se sentaban en frente de ella, en otros casos, como el panorama Mesdag en La Haya (1881) - actualmente en funcionamiento - el público recorría el espacio en un ejercicio de integración corporal con la pintura; para poder seguir la narrativa propuesta se vendían a la entrada del espectáculo resúmenes impresos en los cuales se reseñaban las características y acontecimientos más importantes. Otro dispositivo que contribuyó al consumo de experiencias fue el diorama creado por Charles Marie Bouton y Louis J. M. Daguerre en 1822; aunque éste, a diferencia de la obra de Barker, replicaba los postulados de la cámara ya que el observador perdía la autonomía otorgada por el panorama al momento en que resultaban un componente que se sumaba a la mecánica de este aparato: el observador inmóvil tomaba lugar frente a una proyección pictórica semitransparente sin mayor interacción con ésta que mantener su mirada fija en el desarrollo del relato ofrecido. El diorama consistía en un espectáculo colectivo que mostraba en el interior de edificios construidos ex profeso cuadros semitransparentes de hasta 21 por 12 metros; estos cuadros utilizaban persianas y espejos con las cuales manipulaban la luminosidad que provenía de focos ubicados por delante y por detrás de la pintura, de esta manera lograba simular vistas como crepúsculos y amaneceres a través de distintos fundidos encadenados o escenas.

Los dispositivos ópticos tuvieron la particularidad de recurrir a un mediador como el lente de aumento para que el observador pudiera visualizar las representaciones que estos aparatos mostraban; fuera en un soporte monocular o uno binocular la utilización de estos ingenios estaba restringido al uso individual, hecho que asociado a la disminución de la distancia entre la imagen y el ojo contribuía a "generar una intensa impresión de realidad" y a la identificación del espectador con el medio, especialmente en los casos de los aparatos binoculares. Dada la proliferación de "ingenios alternativos" que circularon profusamente entre los 
originales, la confusión aumenta cuando se trata de abordarlos, razón por la que aquí se tratan aquellos reconocidos como los dispositivos ópticos fundacionales si es que habría que denominarlos de alguna manera, a saber: los estereoscopios de Brewster y Wheatstone, el caleidoscopio de Brewster y los Mundo Nuevos o cajas ópticas de facturación anónima.

Las primeras cajas ópticas vieron la luz inspiradas en la antigua cámara oscura a la que se le añadió un lente a través del cual se accedía al interior del recinto, su incorporación al ruedo social implicó el desarrollo de una serie de variantes que añadieron de una a varias oquedades alrededor del cubo que permitían visualizar las pinturas o grabados en su interior; sus temas abarcaban desde vistas de paisajes y ciudades hasta fábulas y acontecimientos de actualidad. Este tipo de artefactos ópticos recorrieron Europa montados sobre un carro tirado por animales y sus nombres variaron según el lugar geográfico en el que se encontraran, aunque siempre derivados de dos expresiones italianas tales como "mondo niovo" y "tutti gli mondi", popularizándose con múltiples variantes: "Mundinovo", "Mondoniovo", "Mondinovi", "Totilimondi", "Peep show", "Mundonuevo", "Mundinuevo", Tutilimundi" o "Titirimundi". A comienzos del siglo XVIII las primeras vistas de estas máquinas ópticas procedentes de los siglos XVI y XVII dieron paso a una nueva generación con escenas en grabados realizadas exclusivamente para estos aparatos las que presentaban vistas panorámicas o el detalle de una gran variedad de temas, su producción y distribución alcanzó hasta la segunda mitad del siglo XIX cuando fueron reemplazadas por tomas fotográficas y la popularidad del aparato no mermo hasta bien entrada la segunda década del siglo XX. En 1815 el científico y naturalista escocés David Brewster inventó el caleidoscopio un aparato que así como la caja de perspectivas, se valió de superficies reflectantes para lograr el efecto óptico de multiplicación que permitió la producción de un número ilimitado de dibujos simétricos y cambiantes; el ingenio de Brewster consistía en un cilindro en cuyo interior y a todo su largo se encontraban dos espejos en 45 grados, al fondo de éste había un depósito en el que se encontraban pequeños trozos de cristal pintados y en el otro extremo un diminuto orificio a modo de visor; así configurado el aparato, al observar su interior y al hacer girar el cilindro, las formas y colores se multiplicaban amén de ambos juegos de espejos y de las decenas de fragmentos multicolor. Es interesante el surgimiento de este aparato ya que su advenimiento se instala en pleno auge del paradigma industrial, modelo que cobijó los estudios fisiológicos que normaban y cuantificaban el cuerpo humano; en este marco, se afirmaba que la belleza estaba regulada por la simetría que se podía observar en la naturaleza y que debía predominar en las artes, de ahí que su creación se justificaba en la medida que el caleidoscopio era un medio mecánico, eficiente y productivo para reformar el arte de acuerdo a los principios dictados por dicho paradigma. El origen del visor estereoscópico de instala en pleno proceso de indagaciones fisiológicas de principios del XIX, de hecho los personajes que comúnmente se asocia con este dispositivo habían escrito extensamente sobre ilusiones ópticas, teoría del color, post-imágenes y otros fenómenos visuales, incluso se habían acercado a los trabajos de Purkinje. El problema de la disparidad ocular fue el problema que el estereoscopio vino a resolver, primero porque el aparato logró que cada ojo mirara como si mirara 
directamente a un objeto y segundo, ya que el visor consiguió que los ojos convergieran y enfocaran como si estuvieran observando al objeto original. En 1838 Charles Wheatstone diseñó un soporte que constaba de dos espejos ubicados frente a la línea de visión del individuo, éstos se orientaban en 45 grados hacia afuera de tal manera que cada uno de ellos reflejaba una imagen fotográfica que variaba la una de la otra sólo por el desplazamiento de la posición de la cámara cuando se hacia una segunda toma de la misma escena. La desventaja del procedimiento de Wheatstone radicó en que el reflejo en los espejos invierte la imagen observada por lo que se "había que obtener las copias con el negativo invertido para que la imagen estereoscópica resultante apareciera en su posición correcta". En 1849, David Brewster proyectó un visor con base en un nuevo principio que situaba el par de fotografías estereoscópicas justo por delante de la línea de visión del individuo a una distancia determinada, todo mediado en principio por unos prismas planos, el efecto que se produjo fue la fusión de ambas imágenes en el cerebro del sujeto obteniéndose una tercera proyección con una notable profundidad de campo; al poco tiempo tales prismas fueron cambiados por otros lenticulares con los que se pudo ampliar la imagen que proyectaban las fotografías y fue este modelo definitivamente el que fue popularizado y clonado profusamente durante todo el siglo XIX.

Un aparato en cuya naturaleza se funden aspectos ópticos y mecánicos es la linterna mágica, artilugio que contemporáneamente se podría asociar con el video beam, con los proyectores de transparencias o de diapositivas. La característica fundamental de este aparato fue su capacidad de descorporeizar y proyectar las imágenes reales con las cuales se pretendía narrar una acción; hasta ese momento - con la notable excepción del teatro óptico de Reynaud - el observador tenía que situar su mirada sobre las gráficas mismas o sobre su reflejo directo para poder disfrutar de la ilusión del movimiento. Con la llegada de la linterna mágica, el espectador abandona el soporte material relevándolo por su reproducción etérea la cual era reconstituida sobre una tela. La linterna mágica consistió en una caja de madera o metal en cuyo interior se encontraba una fuente de luz - al principio una vela, luego gas y más tarde una ampolleta eléctrica -, en su cara frontal se hallaba un tubo con un lente en cada extremo de éste; al acoplarse el tubo al cuerpo de la cámara quedaba una ranura en la que se colocaban unas pequeñas placas de cristal translúcido a través de las que pasaba la luz del interior del aparato para salir proyectadas por el extremo opuesto del tubo. Como queda en evidencia, el principio óptico de esta caja era inverso al de la cámara oscura, esto es, que para lograr el efecto de proyección en la linterna mágica el espacio iluminado debía encontrarse en el interior de ella y el espacio exterior era el que debía permanecer en penumbras; por el contrario, en el caso de la cámara oscura, el espacio exterior era el que debía estar alumbrado y el interior de ésta a oscuras para lograr el efecto de intra-proyección. Los perfeccionamientos técnicos que sucedieron a las primeras linternas y su empleo como recurso académico y de entretenimiento entre los siglos XVII y XIX dieron al aparato un papel central como instrumento de transformación social, especialmente a partir de la Revolución Francesa 
cuando a través de ellas y de los linternistas que las cargaron, las narrativas que presentaban compartieron junto a los temas alegóricos y fantásticos la crítica contra los privilegios de la nobleza y la monarquía.

El dominio sobre la "mecánica oscura" dio pie a la creación de un espectáculo-medio que marcó la mayoría de edad de la linterna mágica y de sus posibilidades expresivas: las fantasmagorías. Hasta mediados del siglo XVIII, la linterna mágica fue utilizada como un sistema de proyección único y estático, anclado a una base sólida sin ningún otro complemento técnico más que el relato que pudiera hacer de la historia el narrador-linternista; será a partir de los años ochenta del siglo XVIII cuando un gesto técnico sencillo pero significativo, el complemento con otros aparatos y el tratamiento de nuevas temáticas acordes con los miedos de una sociedad en tránsito hacia la modernización industrial, los elementos que dotarán al dispositivo de un modo de expresión específico. El clérigo belga Étienne-Gaspard Robert, conocido como Robertson, junto a otros contemporáneos repararon en el interés que generaba el abordaje de temas espectrales en la sociedad del momento, así fue como crearon un género audiovisual que tuvo a la muerte como la principal fuente de inspiración; a través de una linterna mágica montada sobre una base móvil hombres como Robertson lograron que la imagen estática que ésta proyectaba fuera aumentando o disminuyendo sus dimensiones así como nublándose o definiéndose mejor conforme se acercaba o alejaba de la tela sobre la cual se disparaban las imágenes, el nuevo aparato fue denominado como fantoscopio, pieza fundamental mas no la única del espectáculo fantasmagórico. En el complejo entramado técnico de las fantasmagorías convergían distintos medios a la hora de generar sobreimpresiones, fundidos, apariciones fantásticas y atmósferas sonoras, a la ya mencionada linterna rodante, debe añadirse otra "normal" que proyectaba figuras estáticas; la utilización del humo como otra superficie sobre la que reflejar la trama; instrumentos musicales, trucos y variados dispositivos creados para ambientar de manera audible las escenas, amén de la propia voz del linternista. Este conjunto de elementos consolidó un género audiovisual que sobrepasó por mucho a los espectáculos de linterna mágica que lo precedieron, incluso llegó a inspirar a los primeros directores de cine primitivo no solo en la temática sino que también en los recursos técnicos con los cuales llegar a desarrollarla.

No pueden quedar fuera de este apartado los aparatos producto de las indagaciones realizadas por una serie de fisiólogos y fotógrafos que buscaron desentrañar la mecánica del movimiento del ser humano y de los animales puesto que, así como los dispositivos hasta aquí vistos, hacen parte también del paradigma positivista dominante en el siglo XIX. Los estudios cronofotográficos consistieron en un conjunto de investigaciones que se propusieron, a través de la descomposición del movimiento en una serie de fotografías sucesivas tomadas a gran velocidad y su reconstrucción mediante el encadenamiento de las mismas, el análisis de la dinámica móvil de objetos y seres vivos. Aunque estos estudios pueden considerarse los predecesores del cine puesto que fueron los que definieron los primeros estándares de la 
captura y de la reproducción de las imágenes (doce fotogramas por segundo), para el astrónomo francés, inventor del revolver fotográfico, Pierre Jules Janssen, la cronofotografía marcó una diferencia con los primeros esfuerzos cinematográficos ya que ésta se inclinaba por darle a sus investigaciones usos científicos y pedagógicos mientras que los segundos, a los que denominaba "fotografía animada" estaban siendo creados con otros fines que perseguían la espectacularidad de la proyección. Janssen, el fotógrafo británico Eadward Muybridge y el fisiólogo francés Étienne-Jules Marey se consideran la vanguardia en este tipo de estudios, el inglés ya que fue el creador del zoopraxinoscopio, un proyector que recogía el principio de la rueda fenaquisticópica y que utilizaba una linterna mágica para las proyecciones públicas de sus tomas fotográficas, trabajo ampliamente difundido en sus libros Animals in Motion (1899) y The Human Figure in Motion (1901); Marey por su lado, fue el inventor del fusil fotográfico, una suerte de escopeta en cuyo cargador se portaban las placas que serían impresas al pasar por el obturador que se encontraba en la base del cañón; Janssen a quien también se le adjudica la creación de un revolver fotográfico, y reconocido por Marey como el "padre" de la cronofotografía móvil, se dedico antes que captar movimientos rápidos, a la captura de fotogramas a largos intervalos, quizá por su formación astronómica. Es interesante destacar que los avances en estos tres casos y en otros contemporáneos a ellos, no hubieran sido posibles sin los adelantos en la técnica y en los soportes fotográficos: flexibilidad, sensibilidad, longitud de la cinta. Penetrar en las especificidades de la técnica fotográfica aplicada a la gran cantidad de aparatos creados para la captura y reproducción del movimiento desborda el estrecho margen de esta maqueta dedicada a los aparatos óptico-mecánicos que contribuyeron a la consolidación de un nuevo observador y a sembrar la semilla de la curiosidad que germinará fines del siglo XIX en los múltiples dispositivos de proyección cinética. Quizá lo que queda por atender es la presencia de los aparatos precinematográficos en el Valle o en Cali y cómo ha sido el desarrollo de la cinematografía en el departamento.

\subsection{La llegada del cine a Cali}

El año de 1897 resulta inaugural para la historia de la cinematografía en Colombia puesto que entre los meses de abril y junio hicieron presencia en el antiguo territorio colombiano de Puerto Colón, hoy Panamá, y en la ciudad de Panamá los aparatos creados por Edison y por los Lumière a través de distintas vías: para el caso de los hermanos franceses un emisario llegó directo desde Europa cargando el cinematógrafo, mientras que el artefacto del inventor estadounidense llegó de la mano de un empresario francés de espectáculos ambulantes, el vitascopio. Dentro de las actuales fronteras colombianas Bucaramanga y Cartagena conocieron en agosto de ese mismo año el aparato de Edison; el 1 de septiembre de 1897

hizo su aparición en la sociedad bogotana el aparato de los Lumière, lo mismo que en no- 
viembre de 1898 en Medellín y en julio de 1899 en Cali. De estos primeros tiempos resulta interesante destacar el enfrentamiento no declarado por la supremacía de uno y otro aparato, aunque en algunos casos, y dada la ignorancia temprana respecto de los mismos, los unos se presentaron bajo el título de los otros tal como sucedió con la primera proyección desarrollada en Cali y una nota de prensa titulada bajo el nombre del aparato de Edison, "Proyectoscopio", cuando la función ofrecida correspondía a la del cinematógrafo de los Lumière. De la lectura de este artículo periodístico se develan las circunstancias técnicas que se impondrán cuando se trate de la adopción popular y del uso futuro del aparato, a diferencia del vitascopio que proyectaba secuencias predefinidas, generalmente grabadas en la casa matriz, el cinematógrafo era contenedor de dos funciones complementarias: el registro y la proyección, de manera tal que al filmar y presentar vistas de lugares reconocidos a la audiencia local, el cinematógrafo se estaba granjeando el éxito que gozaría durante el siglo XX. Precisamente, Cali será el lugar en donde por primera vez en Colombia se filmarán y proyectarán distintas vistas de la capital del Valle, velada que tuvo lugar en el desaparecido Teatro Borrero los días cercanos al 16 de junio de 1899.

El mismo puerto Colón por donde un lustro antes habían atracado los empresarios trashumantes del primer cine, vio llegar en 1903 a los que serían reconocidos como unos de los pioneros del cine colombiano, la familia Di Domènico con los hermanos Francisco y Vicente a la cabeza. Procedentes de Martinica en donde habían cambiado el giro de su tienda de textiles por el de la exhibición cinematográfica, llegaron a Colombia en vista de lo incipiente del rubro y de las dimensiones geográficas del país lo que garantizaba un éxito mayor que el que les permitía la isla caribeña. El éxito de las primeras funciones desarrolladas en Bogotá en 1909, permitió a “Di Domènico Hnos. \& Cía” construir en 1912 el teatro Olympia, un escenario para tres mil personas en donde se exhibieron películas italianas y francesas y en menor medida norteamericanas. La construcción del teatro, la creación de la Sociedad Industrial Cinematográfica Latinoamericana - Sicla - en 1914 y la edición de revistas a tono con la incipiente industria son algunos ejemplos acerca de cómo los Di Domènico comprendieron desde un principio el negocio del cine, el que para inicios del siglo XX era una alternativa efectiva a la asistencia a oficios religiosos dominicales. El cortometraje La fiesta del Corpus (1915) inauguró la producción cinematográfica de Sicla, cinta que fue catalogada en su momento como "la primera película nacional", durante ese mismo año se estrenó El drama del 15 de octubre, una suerte de documental que trataba el asesinato del General liberal Rafael Uribe (1859-1814) a través de las captura de escenas de su autopsia, de la reconstitución de escena por sus asesinos y de las confesiones de los autores del magnicidio en el antiguo panóptico de Bogotá. Luego del lanzamiento de este último trabajo, los Di Domènico no produjeron nuevos materiales hasta principios de los años veinte quizá motivados por la aparición de otra familia pionera en el cine colombiano y por el exitoso estreno en celuloide del clásico de Jorge Isaac, María en 1922. Entre 1924 y 1926 los Di Domènico estrenaron cuatro largometrajes con innegable éxito comercial que se sostuvo en distintas estrategias: Aurora y las 
Violetas (1924), llevó a la pantalla grande la popular obra homónima de José María Vargas Vila, Conquistadores del almas (1925) se llevó del teatro al celuloide luego de que la junta de censura prohibiera su exhibición, quizá debiéndose ahí su éxito, por el gusto por lo prohibido. En 1925 se estrenó Como los muertos, cinta adaptada de su homónima teatral escrita por el dramaturgo Antonio Álvarez Lleras, estrenada en 1916 fue montada hasta bien entrada la década de los 30 y El amor, el deber y el crimen (1926), cinta cuyo éxito fue menor al de las películas que la precedieron. Como señala el texto de la Fundación Patrimonio Fílmico Colombiano (2012), la rentabilización de las películas producidas por Sicla llamó la atención de un conjunto de empresarios antioqueños que agrupados en Cine Colombia propusieron a los Di Domènico la compra de la Sociedad, quizá la pregunta que habría que responder aquí es si la producción de estas películas dejó resultados positivos en las finanzas de Sicla, ¿qué llevó a tomar la decisión de venta de la empresa? La respuesta se halla en la obra de Salcedo (1985) quien interroga por lo mismo a uno de los últimos Di Domènico que vivió in situ la bonanza cinematográfica: "Por una razón muy sencilla: porque la propuesta de Cine Colombia convenía a todos los socios de la compañía Di Domènico Hermanos y, además, por ciertas diferencias que surgieron entre los mismos socios."

Otro grupo de pioneros en el cine nacional fue la familia bogotana encabezada por Arturo Acevedo Vallarino y sus hijos Gonzalo y Álvaro Acevedo Bernal. Acevedo Vallarino, en principio ligado a la escena teatral, vio en el cine una alternativa frente al alicaído teatro nacional del que también fue uno de sus más entusiastas impulsores: fundó grupos como la Scala de Chapinero y la Compañía Dramática Nacional, así como la Sociedad de Autores Nacionales. En los años veinte del siglo XX el cine desplazó al teatro como alternativa lúdica hecho que catalizó el "giro artístico" de Acevedo el que inició proyectando cine extranjero en el teatro El Bosque de Bogotá. Acevedo e hijos inauguran su tradición cinéfila cerca de 1924 filmando los acontecimientos más sobresalientes de la capital de la República como los carnavales estudiantiles, las carreras de caballos, los reinados de belleza y otros eventos sociales que recibieron el nombre de Noticiero Nacional, material exhibido antes de la proyección de cada película principal. La grabación del noticiero tuvo un propósito específico como fue ganar experiencia en materia fílmica para poder producir y realizar sus propios largometrajes, así durante ese mismo año los Acevedo crearon Casa Cinematográfica Colombia firma con la que produjeron "la primera película auténticamente colombiana", estrenada en las fiestas patrias del 20 de julio de 1924 y recibida positivamente por el público, el clero y los gobernantes de turno: La tragedia del silencio. El hecho que los Acevedo hubieran registrado el cóctel de inauguración de la Casa Cinematográfica junto a la publicación de la revista Cine Colombiana órgano de difusión de ésta, demuestra para Historia del cine colombiano que más allá del puro interés comercial de los Acevedo por el cine lo que se estaba gestando era un modo de expresión nacional. El éxito cosechado por La tragedia del silencio permitió a los Acevedo en asocio con un empresario antioqueño, realizar "la superproducción colombiana del cine silente": Bajo el cielo antioqueño (1925). Escrita y dirigida por Acevedo Vallarino su 
financiamiento se realizó mediante la venta de acciones realizada por la Compañía Filmadora de Medellín, estrenándose en el teatro Junín de la capital de Antioquia. El reconocimiento otorgado al Noticiario Nacional llevó a que Casa Cinematográfica Colombia se asociara a Cine Colombia para la producción conjunta del Noticiero Cineco a partir de 1929 hasta 1932 año en el que esta última resolvió dejar de pagar el diez por ciento por la exhibición de cada noticiero, lo que obligó a los Acevedo a suspender este noticiero y a retomar la producción del Noticiero Nacional y la filmación de distintos tipos de documentales. De esa manera fue que éstos produjeron una serie de cortometrajes de carácter institucional y a lo menos tres largometrajes: Colombia victoriosa (1933) cuyo argumento fue la guerra contra el Perú, La apoteosis de Olaya Herrera (1937) que trató el retorno del féretro de Olaya desde Buenaventura hasta Bogotá y la película Los primeros ensayos del cine parlante nacional (1937) obra que da cuenta de los avances alcanzados en materia sonora por el ingeniero alemán Carlos Schroeder.

Para Oswaldo Osorio (2005) la "primera muerte del cine colombiano" ocurrió con la creación de Cine Colombia ya que ésta privilegiaba la proyección de cine extranjero éxito de taquilla que adquiría a bajo costo y que explotaba en todo el territorio colombiano, antes que producir películas nacionales que para su realización era necesario un desembolso importante de recursos. Al comprar Sicla, sociedad propietaria de uno de los pocos laboratorios para el revelado de películas, al clausurar éstos y rematar el capital tecnológico de la empresa se desincentivó gran parte de la creación cinematográfica en el país. Sin embargo, no hay que buscar en Cine Colombia los motivos exclusivos del ocaso del cine colombiano de las primeras décadas del siglo XX, para el cronista Hernando Salcedo (1981) gran parte de la responsabilidad recae en los gobiernos que no se interesaron en fomentar una industria nacional, cosa que si hubiera ocurrido el cine colombiano podría compararse con el argentino, el brasileño o el mexicano; tal hipótesis se refrenda en una de las entrevistas que presenta: la realizada a Donato Di Domènico. Una vez vendida Sicla, Vicente Di Domènico se radicó en Barcelona en donde instaló un laboratorio cinematográfico, sin embargo al estallar la Guerra Civil española (1936-1939) decidió volver a Colombia e instalarlo en Bogotá. La tarea administrativa se le encargó a Donato quien acusó en su momento que a pesar de todo tipo de trámites realizados, las diligencias por instalar el laboratorio en la capital fueron inútiles sobre todo por "la indiferencia que por el proyecto demostraron tanto el gobierno como los particulares". Pero las causas fueron más estructurales que un problema de aduanas ya que a lo restringido del capital que se invertía en la producción, habría que añadir la ausencia de una reflexión y una crítica acerca de lo que el cine nacional estaba produciendo, aspecto que obliga a observar un tercer elemento: el factor argumental en la producción colombiana. Al depender ésta de la copia de modelos europeos, lo que se hacía era abonar el gusto por estéticas importadas y disolver el interés del público por la gramática iconográfica local con la que se intentaba escribir el cine nacional. A lo anterior hay que agregar el atraso tecnológico, puesto que aunque en Colombia Carlos Schroeder desarrolló en 1930 el "cronofotófono" en 
el país no se implantó la técnica estándar de reproducción de sonido sino que hasta 1939, cuando en Hollywood ésta se venía utilizando desde 1927.

También desde Panamá (Balboa) hizo su entrada a escena en la historia del cine colombiano el fotógrafo español Máximo Calvo quien junto a Alfredo del Diestro filmó María, la novela homónima de Jorge Isaacs. Impulsado por el médico y sacerdote franciscano Antonio José Posada, Calvo llegó a Cali en 1921 convencido del éxito que una novela como María podía tener al presentarla en pantalla; Del Diestro, de gira con una compañía teatral en la capital del Valle, fue contactado por el sacerdote para co-dirigir lo que se ha dado en llamar el primer largometraje de ficción y el primer clásico del cine colombiano. Calvo, fotógrafo de formación con experiencia en el rodaje de películas operó cámaras, fotografío escenas fijas, reveló, editó y positivó la película, mientras que Del Diestro adaptó el guión, estuvo a cargo de la dirección artística de la producción y co-dirigió la obra. A principios de la década de los veinte del siglo XX, el cine había adquirido cierta popularidad en el país por lo que la búsqueda de financiamiento para llevar al celuloide una obra nacional de origen valluno, encontró una pronta respuesta entre los miembros de la clase acomodada de la región, entre ellos los Salcedo de Buga y Federico López, diplomático colombiano, quienes en conjunto crearon la Valley Film Company. María se estrenó en octubre de 1922 en Buga y en el Gran Salón Moderno de Cali con un importante reconocimiento del público y de la prensa los que destacaban la fidelidad con la obra literaria; el éxito alcanzado por la película obligó a Calvo a realizar varias copias para su distribución en Colombia y en los países de habla hispana. Así como los Acevedo con su Noticiario Nacional, los Di Domènico con Sicla-Journal, Máximo Calvo realizó una serie de "revistas cinematográficas" así como cortos publicitarios para distintas empresas de la época, incluso después de haber dejado de hacer cine en la segunda mitad de la década de los cuarenta. Participó con la cámara en el rodaje de Nido de cóndores en 1926, una obra producida por la Sociedad de Mejoras Públicas de Pereira y dirigida Alfonso Mejía Robledo, quien también trabajó el guión; con base en una historia de amor, la película mostraba en seis partes los eventos asociados a la fundación de la ciudad (1863) y el desarrollo que ésta había experimento en 63 años de existencia, estrenándose el 23 de noviembre en el Teatro Caldas de Pereira. Con la Calvo Film Company, creada entre 1936-1938, el fotógrafo español estrenó en el Teatro Jorge Isaacs de Cali Flores del Valle (1941), un largometraje musical costumbrista que narra las vicisitudes de una joven campesina que hace su estreno social en la ciudad, aunque en 1938 ya se había filmado Al son de las guitarras es a Flores del Valle a la que se considera la primera película argumental parlante y sonora de Colombia. Al son de las guitarras al parecer fue una película inacabada de Alberto Santana y Carlos Schroeder, se trató de otro argumental musical esta vez filmado en Bogotá que jamás llegó a estrenarse. La segunda producción de la Calvo Film Company fue el largometraje de 1944 Castigo del fanfarrón, obra en la que el bien y el mal se enfrentan personificados en un pobre campesino y un rico hacendado los que se disputan el amor de una mujer; según hace constar Salcedo, la exhibición de esta obra fue aplazada indefinidamente por dificultades con la 
compañía. Máximo Calvo dejó de lado la producción cinematográfica después de haber terminado "Castigo..." ya que consideraba que había trabas para la producción nacional tanto de parte del sector público como del privado, de este último acusó que los exhibidores privilegiaban al cine extranjero presionados por los distribuidores de éste quienes condicionaban los días y horas de proyección, mientras que desde el ámbito público no había una ley que protegiera al cine nacional.

Del llamado período silente del cine colombiano y de los primeros intentos por concebir un cine sonoro nacional (1921-1937) vale la pena destacar dos aspectos relacionados, el primero tiene que ver con la cantidad de casas cinematográficas que se volcaron a la producción de un cine nacional y el segundo con la cantidad de filmes rodados por ellas. En efecto, las primeras tres décadas del siglo XX son fundacionales para la cinematografía colombiana puesto que con capitales, actores y guiones locales se rodaron y exhibieron en teatros construidos ex profeso o en espacios habilitados para la proyección pública cinematográfica como los ruedos de madera construidos para las corridas de toro - cerca de 22 producciones $^{2}$ varias de las cuales ya han sido señaladas en estas líneas. La riqueza de la producción cinematográfica nacional en esta primera etapa es tributaria de la creación de distintas sociedades productoras regionales que permitieron la descentralización del rodaje de cintas y su producción en distintas ciudades del país, a pesar que al poco andar del estreno de sus operas primas varias de éstas hayan desaparecido como fue el caso de la Sociedad Filmadora del Tolima S.C que estrenó en 1928 Los amores del Quelif considerada la última producción silente del cine colombiano; durante la itinerancia "del Quelif" la película de nitrato ardió llevándose con ella no solo la única copia de la cinta sino que también el emprendimiento cinematográfico de la sociedad organizada por Carlos Arturo Sanín Restrepo - director de la cinta - en El Líbano, Tolima. A las ya mencionadas Sicla, Casa Cinematográfica Colombia (Acevedo e Hijos) y Calvo Film Company, habría que sumar a la Manizales Film Company, sociedad que estrenó entre 1924 y 1925 dos largometrajes (Madre y Manizales City). En el ámbito local se creó la sociedad cinematográfica Colombia Film Company (1923) conformada por un grupo de hombres de negocios del Valle. Es importante detenerse un momento en

2 Carnaval de Barranquilla, Floro Manco (1914, documental), El drama del 15 de octubre, Vicente Di Domenico (1915, documental). De BarranquiIla a Santa Marta, Floro Manco (1916, largometraje documental). De Barranquilla a Cartagena, Floro Manco (1916, largometraje documental). El triunfo de la Fe, Floro Manco (1918, corto publicitario). María, Máximo Calvo Olmedo y Alfredo del Diestro (1922, ficción). Aurora o las Violetas, Pedro Moreno Garzón y Vicente Di Domenico (1924, ficción). Madre, Samuel Velásquez (1924, ficción, silente). La tragedia del silencio, Arturo Acevedo Vallarino (1924, ficción). Bajo el cielo antioqueño, Arturo Acevedo Vallarino (1925, ficción). Como los muertos, Pedro Moreno Garzón y Vicente Di Domenico (1925, ficción). Conquistadores de almas, Pedro Moreno Garzón (1925, ficción). Manizales City, Félix R. Restrepo (1925, documental). Suerte y azar, Camilo Cantinazi (1925, ficción). Alma provinciana, Félix Joaquín Rodríguez (1926, ficción). El amor, el deber y el crimen, Pedro Moreno Garzón y Vicente Di Domenico (1926, ficción). Garras de oro (The dawn of justice), P. P. Jambrina, seudónimo de Alfonso Martínez Velasco (1926, ficción). Nido de cóndores, Alfonso Mejía Robledo-Máximo Calvo (1926, ficción). Tuya es la culpa, Camilo Cantinazzi (1926, ficción). Los amores de Quelif, Carlos Arturo Sanín Restrepo (1928, ficción). Rafael Uribe Uribe o el fin de las guerras civiles en Colombia (Caminos de gloria), Pedro J. Vásquez (1928, ficción). Colombia victoriosa, Gonzalo y Álvaro Acevedo Bernal (1933, ficcio-documental). Olaya 
la historia de la "Colombia Film" puesto que fue una de las pocas compañías, aparte de la Sicla, que en las instalaciones de Cali tuvo sus propios laboratorios de revelado, asimismo, importó no sólo filmadoras y proyectores sino que también elementos decorativos que sirvieron para ambientar sus producciones, incluso llegó a contratar en el extranjero personal técnico (director y camarógrafo) y artístico (las actrices italianas Lyda Restivo, recordada como Mara Meba, y Gina Buzaki). Las primeras producciones de esta sociedad fueron unos "dramas sentimentales y costumbristas" que se estrenaron en el desaparecido Teatro Moderno de Cali, espacio que hoy ocupa el Teatro Jorge Isaacs, cintas que fueron bien recibidas por la audiencia: Suerte y azar (1925) y Tuya es la culpa (1926). La tercera producción fue un cortometraje realizado en 1927, Tardes Vallecaucanas, que presentó los paisajes y las ciudades del Valle. La Colombia Film Company, así como las otras productoras, fue fundada pensando en la realización de películas que abordarán temáticas históricas y literarias como El alférez real de Eustaquio Palacios y Tierra nativa de Isaías Gamboa pero dificultades en la distribución nacional e internacional del material, la competencia con el cine extranjero y los resultados económicos negativos producto de la inexperiencia en casi todos los ámbitos cinematográficos obligaron el cierre de la compañía. Aunque también se especula que esta sociedad bajo el rótulo de Cali Film fue responsable de la producción de la primera película "antiimperialista del cine mundial": Garras de oro (1926), ello ya que según el supuesto del investigador Ramiro Arbeláez, uno de los accionistas de la "Colombia...", Alfonso Martínez Velasco, habría sido el responsable tanto de la contratación de personal extranjero como del rodaje de la cinta, habría que agregar a lo anterior el hecho de que en los bordes de lo intertítulos se hacía explicita la pertenencia de la cinta a la productora caleña Cali Film y si se considera que la "Colombia..." - como se ha señalado - importó material para la decoración de sus escenas, esta hipótesis bien podría darse por cierta. Por último, otro argumento que sostiene esta afirmación se encuentra en los seudónimos usados por el personal técnico que intervino en la cinta, por ejemplo, el nombre del director P. P. Jambrina correspondería al del ex - alcalde y ex - accionista de la Colombia Film Company Alfonso Martínez Velasco. Garras de oro describe los hechos ocurridos entre 1903, año en que se separa Panamá de Colombia y 1914, fecha en la que es inaugurado el Canal, sazonados con un romance entre un periodista estadounidense acusado de calumnia contra, el de aquel entonces, presidente norteamericano Teodoro Roosevelt y la hija del cónsul colombiano en Nueva York; la fineza en el tratamiento de la luz y la riqueza de las perspectivas dadas por la cámara, junto con las locaciones transnacionales para su realización; la ausencia de una arquitectura nacional, de "rostros y perfiles" locales y las críticas a la clase política del momento, abren un flanco que pone en duda si esta cinta es verdaderamente un producto nacional o por el contrario resulta ser un drama extranjero refrito, ajustado, a través del cambio del orden de los rollos y de algunos planos y la inclusión de una que otra imagen de noticiero, a las circunstancias del caso colombiano y su pérdida territorial. Investigaciones recientes podrían dirimir momentáneamente hacia qué lado de la balanza inclinar la historia de Garras de oro o bien pueden 
brindar una tercera perspectiva. Es cierto que el manejo fílmico de la película dista de las producciones nacionales de la época y que trató temas sensibles para la política nacional cuando las superproducciones locales aún miraban los imponentes paisajes que ofrecía la geografía local e insistían en retratar el proceso de modernización colombiano, este hecho de por sí le otorga un valor de distinción a la película, más allá de determinar en qué país se filmó. Se produjo en Italia, fue dirigida por Alfonso Martínez Velasco alias P.P Jambrina y los asistentes técnicos fueron, tal como aparece en la cinta, Arrigo Cinotti y Arnaldo Ricotti; estas pequeñas certezas dan pie para preguntarse por sus incertidumbres, tal como se lo cuestionan los investigadores Suárez y Arbeláez (2010), entre otras, ¿cuál es la versión completa de la cinta? ¿cómo se desarrollaron los procedimientos que la censuraron? ¿quiénes y por qué escondieron la cinta en el interior del Teatro Jorge Isaacs? Garras de oro se estrenó el 13 de marzo de 1927 en el Teatro Moderno de Cali con un lleno total.

Así como casas productoras, también hubo emprendimientos individuales que abrevaron a la producción cinematográfica silente: el colombiano Félix Joaquín Rodríguez y el italiano Floro Manco, son dos de estos ejemplos. Rodríguez, quizá el único colombiano de la época que tuvo un verdadero contacto con el Hollywood de los años veinte, escribió el guión, dirigió, operó la cámara, diseñó la iluminación y realizó la carpintería de la escenografía de su opera prima, no contento con ello reveló una segunda copia de su obra en un improvisado laboratorio. Alma provinciana (1926), una obra realista no solo en el concepto sino que también en la práctica del rodaje contó con un presupuesto reducido y tanto las locaciones - residencias de amigos, paisajes de la sabana y páramos santandereanos -, como los actores que participaron en ella -amigos, conocidos y "gente corriente" - contribuyeron a otorgarle ese aire natural que Rodríguez buscó en su realización. Este exitoso melodrama nacional realista se estrenó el 23 de febrero en el Teatro Faenza en Bogotá. Con el cortometraje de 1914 Carnaval de Barranquilla, los largometrajes De Barranquilla a Santa Marta, De Barranquilla a Cartagena (1916) y el primer corto fílmico de tipo publicitario El triunfo de la Fe (1918), Floro Manco inauguró la tradición documental en Colombia. Desembarcado en Barranquilla en 1905 notó la ausencia de una tienda fotográfica especializada por lo que decidió instalarse definitivamente en el puerto a partir de 1913 y lo hizo no solo con un estudio fotográfico sino que también con la representación oficial de la Casa Kodak. 


\section{GUIÓN CURATORIAL}

\section{Temas}

Presentación

\section{Objetivos}

Presentar el título del proyecto.

Describir de qué tratan los multimedios y cómo se estructuran

\begin{tabular}{|c|c|c|}
\hline Cedulario & $\begin{array}{c}\text { Obra/Apoyos } \\
\text { museográficos } \\
\text { (referencias) }\end{array}$ & $\begin{array}{c}\text { Especificaciones/Referencias } \\
\text { gráficas/Fuentes }\end{array}$ \\
\hline $\begin{array}{l}\text { Cédula introductoria pantalla principal 1 } \\
\text { Con el desarrollo de este recurso multimedial, el } \\
\text { proyecto CiNemotecnia de Cali busca traer al } \\
\text { presente los contextos y los mecanismos que } \\
\text { dieron origen a los aparatos ópticos que } \\
\text { comúnmente se han asociado con la creación del } \\
\text { cinematógrafo. } \\
\text { El término cine proviene de la voz griega kinema } \\
\text { que significa movimiento; en tanto que } \\
\text { mnemotecnia, procede del también griego mnéme } \\
\text { que quiere decir memoria y del sufijo tecnia que } \\
\text { significa técnica, algo así como técnica de memoria. } \\
\text { Así, tenemos que CiNemotecnia de Cali viene a } \\
\text { convertirse en una suerte de técnica de la memoria, } \\
\text { de la recordación de aquellos aparatos ópticos, } \\
\text { creadores de ilusiones, que fascinaron la mirada de } \\
\text { los observadores del siglo XIX y que muy bien } \\
\text { pueden encantar la vista del espectador del XXI. } \\
\text { El itinerario de este multimedio contempla la } \\
\text { revisión de dos grandes temas que en ningún caso } \\
\text { se pretende darlos por acabados con la visita que } \\
\text { aquí se propone, sí se busca, en cambio, } \\
\text { complementar la narrativa principal que se } \\
\text { presenta en las salas de exhibición del museo: } \\
\text { desapareciendo. } \\
\text { se acerca a los distintos ensayos del hombre por } \\
\text { capturar la imagen de la realidad que lo circunda } \\
\text { tal cual es, dinámica y en movimiento: desde los } \\
\text { intentos de los primeros homínidos hasta cuando } \\
\text { ven la luz, bajo el alero del "mundo moderno", los } \\
\text { instrumentos ópticos. }\end{array}$ & & $\begin{array}{l}\text { Diseño en Flash u otro } \\
\text { programa ad-hoc }\end{array}$ \\
\hline
\end{tabular}




\section{Temas}

Núcleo temático 1

En búsqueda de una pre-historia del cine

1.1. Recuerdos de un bisonte

1.2. Aparatos ópticos: entre lo lúdico y lo científico

1.3. La llegada del cine a Cali

\section{Objetivos}

Destacar los albores del "comportamiento simbólico" del sujeto Prehistórico, así como sus manifestaciones culturales que actualmente se asocian con la imagen en movimiento.

Señalar los paradigmas científicos que contextualizaron la emergencia de los distintos aparatos ópticos que comúnmente se han asociado con la creación del cine.

Resaltar la llegada del cine a la ciudad de Cali y los hitos que le han granjeado un lugar al Departamento en la historia de la cinematografía en Colombia

\begin{tabular}{|l|l|l|}
\hline Cedulario & $\begin{array}{c}\text { Obra/Apoyos } \\
\text { museográficos }\end{array}$ & Especificaciones \\
\hline Cédula pantalla 2"Recuerdos de un bisonte" & \\
Introducción & \\
Sería un error tender a pensar que la narración de \\
acontecimientos mediante el uso de la imagen es un producto \\
exclusivo de la modernidad. Es cierto que el relato de una \\
historia realizado a través de la imagen en movimiento, es decir, \\
la proyección sobre una pantalla de una secuencia de imágenes \\
filmadas una a una en rápida sucesión, es un logro reciente de la \\
humanidad - casi 120 años -, sin embargo nos podría \\
sorprender el hecho de encontrar ejercicios similares a lo largo \\
de la historia del hombre.
\end{tabular}




\begin{tabular}{|c|c|}
\hline $\begin{array}{l}\text { Cédula pantalla } 3 \text { "Recuerdos de un bisonte" } \\
\text { Las pinturas rupestres que los primeros humanos } \\
\text { plasmaron en las profundidades de las cavernas } \\
\text { ¿prehistóricas? pueden considerarse los } \\
\text { antecedentes más antiguos del principio de la } \\
\text { animación ¿cinematográfica? Descubrimientos e } \\
\text { investigaciones recientes realizadas en Europa } \\
\text { permiten sostener esta afirmación ya que se han } \\
\text { encontrado en las penumbras de estas milenarias } \\
\text { cuevas, verdades secuencias de la vida silvestre } \\
\text { que alguna vez habitó las montañas y los valles de } \\
\text { algunas regiones de España, Francia y Portugal. Es } \\
\text { más, puede decirse también que estas pinturas } \\
\text { representan la manifestación más temprana de la } \\
\text { aparición del "espíritu humano" ya que reflejan la } \\
\text { capacidad de los hombres prehistóricos para } \\
\text { realizar asociaciones mentales entre personas, } \\
\text { objetos y contextos. Estamos en presencia } \\
\text { entonces del nacimiento del comportamiento } \\
\text { simbólico, el mismo con el que el hombre y la } \\
\text { mujer actual realizan todos sus procesos de } \\
\text { abstracción. } \\
\text { En cuevas de estos tres países como Lascaux, } \\
\text { Chauvet y Foz Coa se han encontrado pinturas } \\
\text { rupestres de } 35 \text { mil años de antigüedad, en donde } \\
\text { se aprecian relatos gráficos que tienen como } \\
\text { protagonistas principales a la fauna de la época } \\
\text { hoy extinta: osos y leones cavernarios, caballos y } \\
\text { bisontes, búhos y águilas, entre otros. Lo más } \\
\text { interesante de esos hallazgos es que pareciera ser } \\
\text { pulidas y, en algunos casos, la piedra fue grabada } \\
\text { dibujo con una antorcha se diera la impresión de } \\
\text { que las pinturas adquirían movimiento. }\end{array}$ & 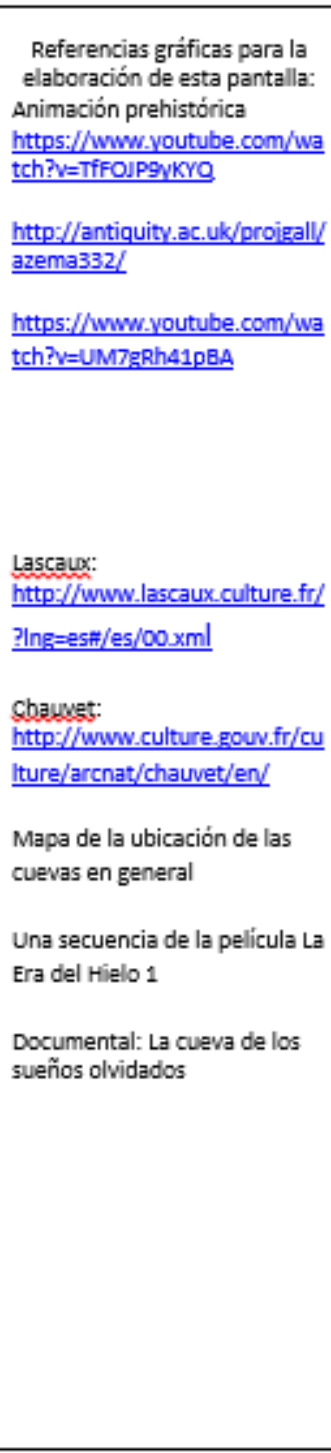 \\
\hline $\begin{array}{l}\text { Cédula pantalla } 4 \text { "Recuerdos de un bisonte" } \\
\text { Es cierto que toda pintura rupestre, dentro de sus } \\
\text { límites, busca contar una historia, también lo es } \\
\text { que la clase de representaciones encontradas en } \\
\text { Lascaux, Chauvet y Foz Coa corresponden a } \\
\text { trabajos más complejos que el común conocido ya } \\
\text { que el movimiento de las pinturas en ellas } \\
\text { encontradas se aleja del "dibujo estático" y } \\
\text { recurre a la superposición de planos para simular } \\
\text { las fases de, por ejemplo, el movimiento de la cola } \\
\text { de un bisonte, o la carrera de un felino que inicia } \\
\text { su cacería. } \\
\text { Es posible afirmar que este tipo de pinturas } \\
\text { inaugura los esfuerzos del ser humano por } \\
\text { transmitir lo que puede observar en su entorno } \\
\text { directo, aunque es necesario mencionar que }\end{array}$ & $\begin{array}{l}\text { - Mopa de } \\
\text { Mesopotamia }\end{array}$ \\
\hline
\end{tabular}


también se han plasmado en ellas los pensamientos míticos de los primeros hombres.

En Mesopotamia, cuna de la civilización occidental, ya que fue allí donde entre el $6.000 \mathrm{a}$.C y el 3.000 a ganadería y la escritura, se hallan los siguientes esfuerzos por contar una historia, en este caso es un relato mítico. En la década de los setenta del siglo XX un equipo de arqueólogos desenterró un pequeño vaso de barro cocido de 5200 años de antigüedad; a su alrededor se encontró grabada una especie de secuencia gráfica que muestra a una cabra - un animal sumamente común en esa región - alimentándose del Árbol de la vida. Si uno gira el vaso cuidadosamente y logra advertir cada uno de los cinco "fotogramas mesopotámicos" podría dar cuenta de los incesantes saltos que da el animal para alcanzar el árbol y comer sus hojas. Es probable que el uso dado a este pequeño cuenco de $13 \mathrm{~cm}$. de alto y $14 \mathrm{~cm}$. de diámetro haya sido ritual. El pequeño vaso se encuentra actualmente en el Museo Nacional de Irán y la única vez que visitó el continente americano fue en una exposición realizada en el año 2007 en México. Este cuenco es considerado por varios investigadores como el inicio de la animación moderna, pero como hemos visto pareciera ser que ella se había instalado en el pensamiento humano con muchos años de anticipación.

Cédula pantalla 5 "Recuerdos de un bisonte" La siguiente estación de nuestro itinerario histórico se encuentra en las tierras del antiguo Egipto. Dentro del conjunto de arte local: arquitectura, escultura, pinturas y bajorrelieves, resulta interesante detenerse en estas dos últimas manifestaciones ya que son ellas las que mejor pueden plasmar la idea de una narración a través de la imagen. Comúnmente, cuando observamos algún bajorrelieve o una pintura egipcia, vemos que sus cuerpos han sido pintados de frente mientras que sus cabezas y extremidades lo han sido de perfil, ello responde a una cosmovisión simbólica particular de ese pueblo ya que se consideraba que la pintura era realmente el "doble" de la persona, razón por lo que ella debía reflejar fielmente al individuo. Y se pensaba, para el caso del rostro y de los ojos, que el perfil en el dibujo podía captar la esencia de la persona y ese es el motivo por el cual se representaba de esa forma.

El caso de la narración de sucesos no escapa a este modelo pictórico. Por ejemplo, esta estela egipcia de 4000 años de antigüedad detalla las

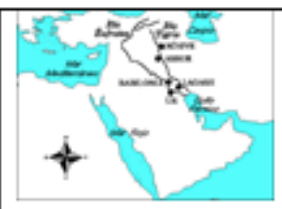

- Video cuenco

- Música tradicional del Irán:

https://www.youtube.com/wa tch?V=9Rk-0aLLV5!

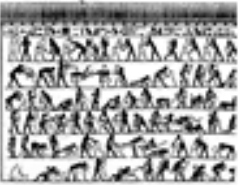

Info. de la imagen de referencia:

http://en.wikipedia.org/wiki/F ile:Esvptmotionseries.jpg

http://www.youtube.com/wat ch?v=wiTcbuxFI-c 


\begin{tabular}{|c|c|c|}
\hline $\begin{array}{l}\text { innumerables posiciones de combate entre dos } \\
\text { luchadores, ambos se encuentran de medio } \\
\text { frente. Si quisiéramos contar qué sucede en esta } \\
\text { estela, deberíamos recortar cada una de las } \\
\text { posturas que los combatientes han asumido y } \\
\text { luego ordenarlas una debajo de la otra, desde la } \\
\text { primera hasta la última. Si estas figuras fueran de } \\
\text { papel y si las ordenáramos como las hojas de un } \\
\text { cuaderno y las hiciéramos pasar una tras otra en } \\
\text { una rápida sucesión de recortes, podríamos ver } \\
\text { una verdadera lucha entre dos gladiadores de } \\
\text { piedra. }\end{array}$ & & \\
\hline $\begin{array}{l}\text { Cédula pantalla } 6 \text { "Recuerdos de un bisonte" } \\
\text { Los teatros de sombras pueden considerarse como } \\
\text { otro tipo de narración histórica conceptualmente } \\
\text { algo más cercana al cine en el sentido de que para } \\
\text { su desarrollo se debe contar con una fuente de luz } \\
\text { y un telón en donde se proyectan las sombras de } \\
\text { unas marionetas. Este tipo de relato gráfico es } \\
\text { conocido popularmente como sombras chinas, sin } \\
\text { embargo, su origen se sitúa en las islas de } \\
\text { Indonesia y Malasia, en el Sureste Asiático. De las } \\
\text { sombras javanesas o Wavapg kulit (woygng: } \\
\text { teatro y kulit: cuero) se tienen antecedentes de } \\
\text { una de las primeras representaciones por el año } \\
900 \text { de nuestra era, no obstante, se estima que su } \\
\text { creación vio la luz unos } 3000 \text { años antes de Cristo. } \\
\text { Con extremidades móviles y elaboradas en cuero } \\
\text { estas marionetas relatan leyendas, escenas de } \\
\text { batallas, entre otras materias, siendo muy } \\
\text { populares en Asia, a tal punto que una variante de } \\
\text { las Woyang kulit utilizan a seres humanos en } \\
\text { reemplazo de las marionetas originales. Así, } \\
\text { tenemos que el teatro de sombras resulta ser otro } \\
\text { de los esfuerzos del ser humano por reproducir el } \\
\text { movimiento, en este caso sobre una pantalla o } \\
\text { telón. }\end{array}$ & & $\begin{array}{l}\text { - Mapa del } \\
\text { Sureste Asiático } \\
\text { - } \frac{\text { http://www.y }}{\text { outube.com/ }} \\
\underline{\text { watch?v=s BF }} \\
\underline{\text { aGdzzwM }}\end{array}$ \\
\hline $\begin{array}{l}\text { Cédula pantalla } 7 \text { "Recuerdos de un bisonte" } \\
\text { En América, un ejemplo de narrativa histórica } \\
\text { vendría a ser los códices mesoamericanos. Los } \\
\text { códices son libros manuscritos pictográficos - es } \\
\text { decir, escritos por medio de dibujos - realizados } \\
\text { por los indígenas de México y Centro América } \\
\text { (mayas, aztecas, mixtecos, zapotecas, otomíes y } \\
\text { purépechas, entre otros) desde antes de la llegada } \\
\text { de los españoles hasta fines del siglo XVIII. En ellos } \\
\text { se cuentan aspectos económicos, sociales, } \\
\text { históricos, científicos y religiosos de esos pueblos. } \\
\text { Ya que para su elaboración se utilizaron } \\
\text { principalmente fibras vegetales, sólo algunos } \\
\text { ejemplares, apenas una veintena, han alcanzado } \\
\text { nuestros días, encontrándose los existentes en las } \\
\text { bibliotecas más importantes de Europa y de } \\
\text { México. } \\
\text { En estos manuscritos prehispánicos los indígenas }\end{array}$ & & 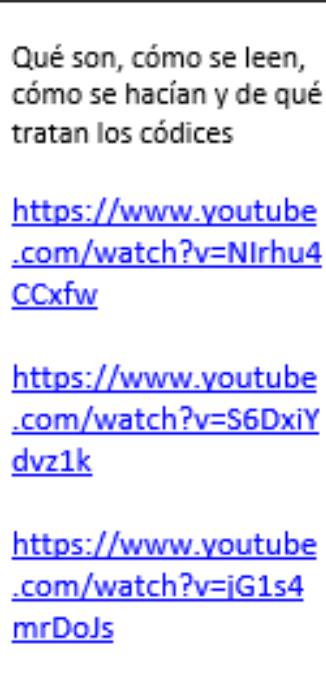 \\
\hline
\end{tabular}




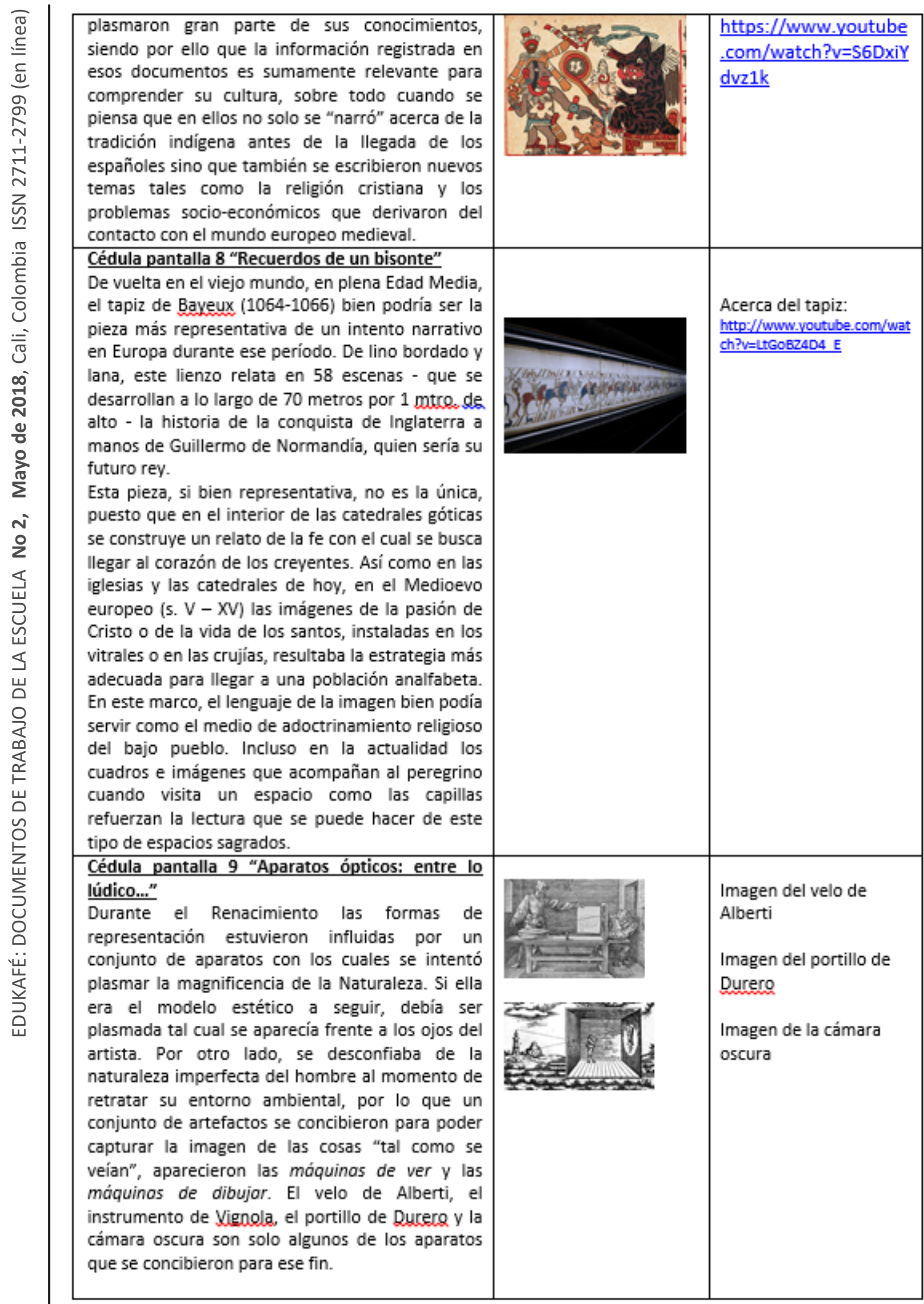


Cédula de pantalla 10

La cámara oscura fue el aparato que instauró una manera de ver el mundo, puesto que a través de ella estudiosos $\mathrm{y}$ artistas del siglo XV hasta fines del XVIII, proyectaron las imágenes utilizadas en sus clases en la universidad, en el caso de los primeros, o representaron los paisajes de la campiña europea, en los segundos. La cámara o habitación oscura consistía en un cuarto absolutamente sellado con lo cual se impedía que la luz del exterior inundara la habitación; en una de sus paredes, en la del frente por ejemplo, se realizaba un pequeño orificio a través del cual penetraba un rayo de sol, de tal manera que poco a poco comenzaba a reflejarse la imagen que provenía del exterior, materializándose invertida en el muro contrario. Esta mecánica de funcionamiento bien podría equipararse al comportamiento del ojo humano.

\section{Cédula de pantalla 11}

Durante el transcurso de los siglos, la mecánica de la cámara oscura no sufrió grandes cambios, más allá de la incorporación de lentes para que la imagen reflejada no estuviera invertida; el aspecto de este artilugio que sí experimentó importantes modificaciones fue el tamaño, a tal punto que de habitaciones y cuartos se pasó a "cajas" oscuras que podían ser transportadas en los bolsillo, incluso carruajes tirados por caballos se habilitaron como cámaras móviles en cuyo interior se podía quedar el artista a la espera de calcor algún paisaje que resultara de su interés, todo sin siquiera salir de su vehículo. Durante 300 años a la cámara oscura se le otorgó la facultad de reemplazar la mirada directa del ojo humano, suplantándola por la relación de Verdad que establecía entre su interior y el exterior de ella, lo que se presentaba frente al ojo dentro de la cámara era lo que se podía representar y no otra cosa que el ojo notural pudiera ver.

\section{Cédula de pantalla 12}

A fines del siglo XVIII y principios del XIX una serie de investigaciones independientes conformó un cuerpo de saberes que tuvo como objeto de indagación el funcionamiento del ojo humano, el resultado de tales investigaciones comenzó a debilitar la idea de la cámara oscura como mediadora entre el sujeto y su entorno. De esta manera, la figura del, por así decirlo, observador mecánico producido por la habitación oscura, dio paso a un observador fisiológico, es decir, un observador cuya experiencia visual ya no estaba mediada por una máquina sino que ocurría al interior de sí mismo. O sea que empezó a cobrar fuerza el hecho de que el cuerpo era la condición

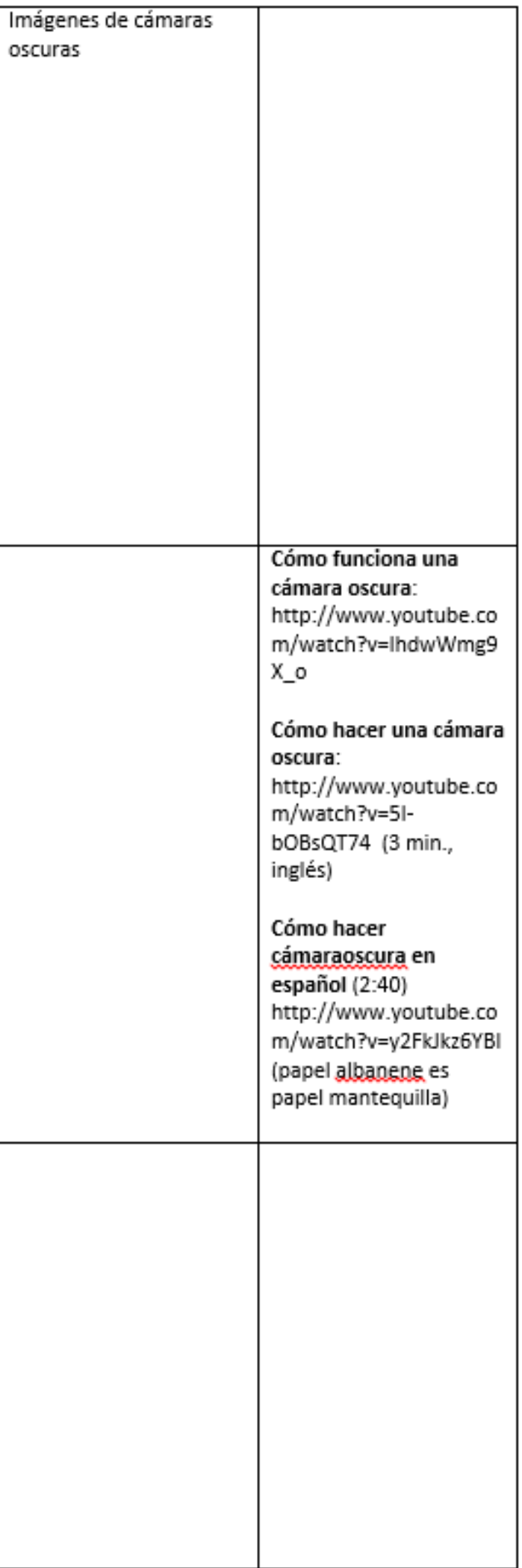




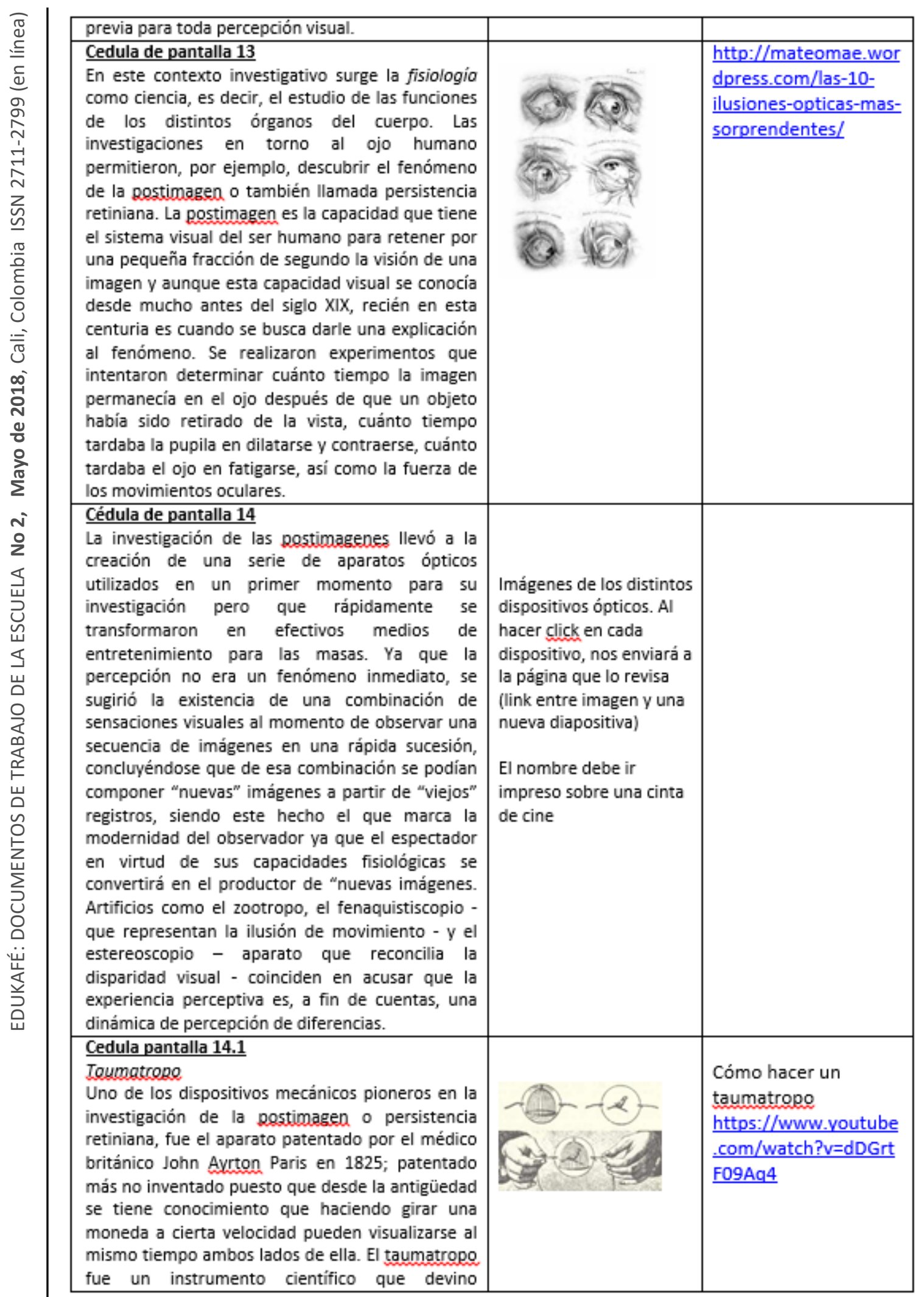




\begin{tabular}{|c|c|}
\hline $\begin{array}{l}\text { rápidamente en juguete óptico, éste consistía en } \\
\text { un disco de cartón con dos imágenes distintas en } \\
\text { cada cara pero relacionadas: un pájaro y una jaula } \\
\text { de pájaro, al hacerlo girar mediante unos hilos } \\
\text { situados a los lados, la visión autónoma del } \\
\text { individuo las fusionaba produciendo una tercera } \\
\text { impresión estática que era en definitiva "Ia gracia" } \\
\text { del dispositivo, es decir, un pájaro dentro de la } \\
\text { jaula. Hay que señalar que este aparato no } \\
\text { buscaba crear una ilusión de movimiento ya que } \\
\text { como se puede ver, la fusión de las dos imágenes } \\
\text { dinámicas creaba una nueva pero fija, al contrario } \\
\text { de otros dispositivos contemporáneos que sí } \\
\text { perseguían esa ilusión. }\end{array}$ & \\
\hline $\begin{array}{l}\text { Cédula pantalla } 14.2 \\
\text { Estroboscopio y fengquisticopio } \\
\text { Diseñados simultáneamente en } 1832 \text { por el } \\
\text { matemático vienes Simon. Bittec. Von Stampfer y } \\
\text { por el físico belga Joseph Antoine Ferdinand } \\
\text { Plateau, el estroboscopio y el fenaquistiscopio, } \\
\text { respectivamente, coincidian en su propósito de } \\
\text { crear la ilusión de movimiento a partir de un disco } \\
\text { giratorio de } 25 \mathrm{~cm} \text {. de diámetro, dividido en } \\
\text { dieciséis secciones iguales que contenían la misma } \\
\text { cantidad de dibujos que sintetizaban las distintas } \\
\text { fases de una secuencia; al hacer rotar la placa } \\
\text { frente a un espejo y al visualizar los diseños a } \\
\text { través de una rendija de un disco traspuesto al de } \\
\text { las imágenes, aspecto técnico incorporado } \\
\text { primero por Stampfer que por Plateay, el } \\
\text { observador podía ver en actividad los distintos } \\
\text { motivos impresos, malabaristas, animales, efectos } \\
\text { ópticos, etc. El principio mecanismo de ambos } \\
\text { aparatos fue muy popular y prolíficamente } \\
\text { "clonado". El fisiólogo checo Purkinje, por } \\
\text { ejemplo, incorporó en un mismo eje el disco con } \\
\text { los dibujos y otro disco-espejo con el cual se doto } \\
\text { de cierta independencia y comodidad al } \\
\text { observador al momento de no tener que } \\
\text { depender de su ubicación frente a una superficie } \\
\text { reflectante, además la estructura de su ingenio } \\
\text { facilitó el cambio del disco de dibujos por otros; } \\
\text { como fisiólogo, el checo optó por imprimir en sus } \\
\text { discos los latidos del corazón, la circulación de la } \\
\text { sangre y diferentes motivos "orgánicos". }\end{array}$ & \\
\hline $\begin{array}{l}\text { Cédula pantalla } 14.3 \\
\text { Zoótropo } \\
\text { Un dispositivo muy popular durante la primera } \\
\text { mitad del siglo XIX fue construido por el } \\
\text { matemático inglés William George Hornet en } \\
\text { 1834: el daedaleum o zoótropo. Este aparato, que } \\
\text { recurrió al efecto la persistencia retiniana para su } \\
\text { funcionamiento, consistía en un tambor de metal } \\
\text { con rendijas que giraba horizontalmente en torno } \\
\text { a un eje central montado en un pequeño soporte; }\end{array}$ & $\begin{array}{l}\text { Una posibilidad } \\
\text { https://www.youtube } \\
\text {.com/watch?v=4l4lCg } \\
\text { Ea69A }\end{array}$ \\
\hline
\end{tabular}




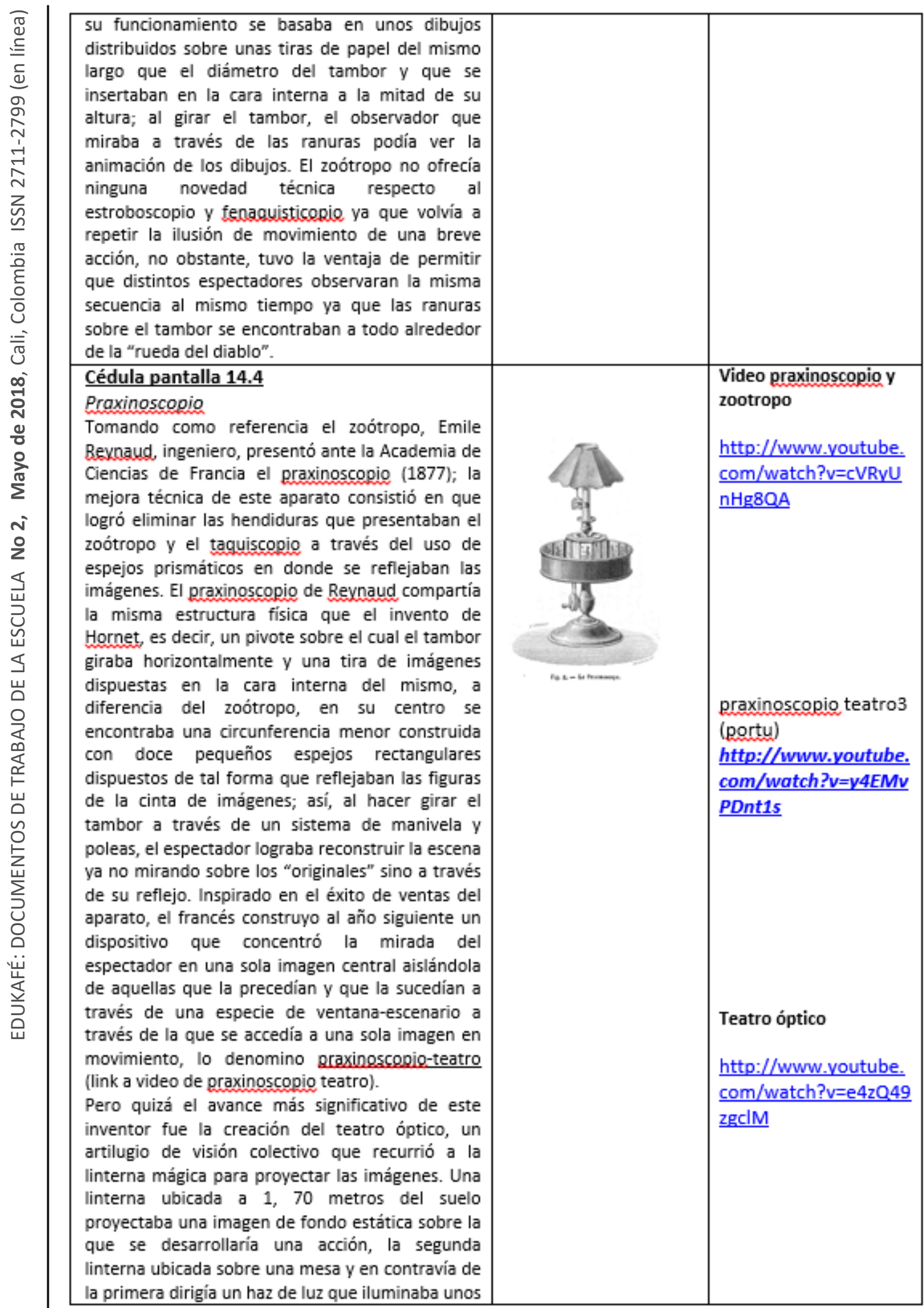




\begin{tabular}{|c|c|}
\hline $\begin{array}{l}\text { fotogramas de diez centímetros cuadrados que } \\
\text { manualmente pasaban delante de ella, dicho haz } \\
\text { de luz, que atravesaba las imágenes, rebotaba } \\
\text { luego en dos espejos lo que permitía que la } \\
\text { segunda impresión alcanzara y coincidiera con la } \\
\text { proyección de fondo. De esa manera, amplificando } \\
\text { el mecanismo técnico del primer Qraxinoscopio, } \\
\text { Reynaud lograba que un artilugio de uso individual } \\
\text { alcanzara dimensiones para-teatrales. }\end{array}$ & \\
\hline $\begin{array}{l}\text { Cédula pantalla } 14.5 \\
\text { Toquiscopio } \\
\text { La aparición de la fotografia introdujo una variante } \\
\text { en los aparatos que se crearon durante la segunda } \\
\text { parte del siglo XIX, no obstante, la mecánica } \\
\text { pestimagen se mantuvo imperturbable, siendo } \\
\text { ésta la que hermana a los de este periodo con los } \\
\text { surgidos en las primeras décadas de ese siglo } \\
\text { como el estroboscopio, fenaquisticopio y } \\
\text { zoótropo. El taguiscopio (1885) del fotógrafo e } \\
\text { inventor alemán Qttomar Anschütz resultaba un } \\
\text { aparato similar al zoótropo con la notable mejora } \\
\text { técnica que permitía que una banda longitudinal } \\
\text { de instantáneas fotográficas conformará el cuerpo } \\
\text { del tambor, cinta sobre la que se hallaban las } \\
\text { hendiduras a través de las cuales el observador } \\
\text { miraba cómo se desarrollaba el movimiento, } \\
\text { asimismo, ya no eran exclusivamente escenas que } \\
\text { se narraban en secuencias horizontales, sino que } \\
\text { al poder girarse el tambor en noventa grados se } \\
\text { daba vida a nuevas escenas que se desenvolvian } \\
\text { verticalmente, como las de ascensos. }\end{array}$ & $\begin{array}{l}\text { Imagen extraída de } \\
\text { Francisco Frutos }\end{array}$ \\
\hline $\begin{array}{l}\text { Cédula pantalla 14.6 } \\
\text { Lienzo panorámico } \\
\text { El panorama consistia en un cuadro de grandes } \\
\text { dimensiones que narraba hechos históricos o que } \\
\text { bien plasmaba motivos urbanos y vistas } \\
\text { panorámicas de las grandes ciudades europeas. } \\
\text { Estas obras de siete metros de alto por cuarenta } \\
\text { metros de ancho - ciento veinte en circunferencia } \\
\text { - se encontraban en el interior de un edificio } \\
\text { cilíndrico dentro del cual se ubicaban los } \\
\text { espectadores; la instalación de la obra en un } \\
\text { espacio de } 360 \text { grados implicó que ésta ocupara } \\
\text { todo el campo visual del observador favoreciendo } \\
\text { de esta manera "la percepción de una tercera } \\
\text { dimensión. En muchos casos la pintura } \\
\text { panorámica rotaba delante de los espectadores } \\
\text { quienes se sentaban en frente de ella, en otros } \\
\text { casos, el público recorría el espacio en un ejercicio } \\
\text { de integración corporal con la pintura; para poder } \\
\text { seguir la narrativa propuesta se vendían a la } \\
\text { entrada del espectáculo resúmenes impresos en } \\
\text { los cuales se reseñaban las características y } \\
\text { acontecimientos más importantes que la } \\
\text { megapintura presentaria. Este tipo de aparato }\end{array}$ & $\begin{array}{l}\text { Referencia panorama } \\
\text { Mesdag } \\
\text { http://panorama- } \\
\underline{\text { mesdag.com/ }}\end{array}$ \\
\hline
\end{tabular}




\begin{tabular}{|c|c|}
\hline $\begin{array}{l}\text { marcó un giro en comparación con la cámara } \\
\text { oscura puesto que a diferencia de ella, en la que el } \\
\text { público debía permanecer estático viendo el } \\
\text { reflejo del exterior, en el lienzo los visitantes } \\
\text { podían caminar libremente por el edificio } \\
\text { acercándose a lo que más les atrajera, de ahí que } \\
\text { se sostenga que este aparato contribuyo a la } \\
\text { constitución de un nuevo tipo de observador. }\end{array}$ & \\
\hline $\begin{array}{l}\text { Cédula pantalla } 14.7 \\
\text { Diorama } \\
\text { Otro dispositivo que contribuyó al consumo de } \\
\text { experiencias fue el diorama creado por Charles } \\
\text { Marie Bouton y Louis J. M. Daguerre en 1822; } \\
\text { aunque éste, a diferencia de la obra de Barker. } \\
\text { replicaba los postulados de la cámara ya que el } \\
\text { observador perdía la autonomía otorgada por el } \\
\text { panorama al momento en que resultaban un } \\
\text { componente que se sumaba a la mecánica de este } \\
\text { aparato: el observador inmóvil tomaba lugar } \\
\text { frente a una proyección pictórica } \\
\text { semitransparente sin mayor interacción con ésta } \\
\text { que mantener su mirada fija en el desarrollo del } \\
\text { relato ofrecido. El diorama consistía en un } \\
\text { espectáculo colectivo que mostraba en el interior } \\
\text { de edificios, construidos ex profeso, cuadros } \\
\text { semitransparentes de hasta } 21 \text { por } 12 \text { metros; } \\
\text { estos cuadros utilizaban persianas y espejos con } \\
\text { las cuales manipulaban la luminosidad que } \\
\text { provenía de focos ubicados por delante y por } \\
\text { detrás de la pintura, de esta manera lograba } \\
\text { simular vistas como crepúsculos y amaneceres a } \\
\text { través de distintos fundidos encadenados o } \\
\text { escenas }\end{array}$ & $\begin{array}{l}\text { http://www.dioraman } \\
\text { ea.com/en/about/ }\end{array}$ \\
\hline $\begin{array}{l}\text { Cédula pantalla } 14.8 \\
\text { Mundos nuevos } \\
\text { Las primeras cajas ópticas vieron la luz inspiradas } \\
\text { en la antigua cámara oscura a la que se le añadió } \\
\text { un lente a través del cual se accedía al interior del } \\
\text { recinto, su incorporación al ruedo social implicó el } \\
\text { desarrollo de una serie de variantes que añadieron } \\
\text { de una a varias oquedades alrededor del cubo que } \\
\text { permitian visualizar las pinturas o grabados en su } \\
\text { interior; sus temas abarcaban desde vistas de } \\
\text { paisajes y ciudades hasta fábulas y } \\
\text { acontecimientos de actualidad. Este tipo de } \\
\text { artefactos ópticos recorrieron Europa montados } \\
\text { sobre carros tirados por animales y sus nombres } \\
\text { variaron según el lugar geográfico en el que se } \\
\text { encontraran, aunque siempre derivados de dos } \\
\text { expresiones italianas tales como "mondo niovo" y } \\
\text { "tutti gli mondi", popularizándose con múltiples } \\
\text { variantes: "Mundinovo", "Mondoniovo", } \\
\text { "Mondinovi", "Totilimondi", "Peeg show", } \\
\text { "Mundonuevo", "Mundinuevg", Tutilimundi" o } \\
\text { "Titirimundi". A comienzos del siglo XVIII las }\end{array}$ & $\begin{array}{l}\text { Referencia } \\
\text { mundonuevo } \\
\text { http://www.museocin } \\
\text { ema.it/vertical dream } \\
\text { s/index.php }\end{array}$ \\
\hline
\end{tabular}




\begin{tabular}{|c|c|}
\hline $\begin{array}{l}\text { primeras vistas de estas máquinas ópticas } \\
\text { procedentes de los siglos XVI y XVII dieron paso a } \\
\text { una nueva generación con escenas en grabados } \\
\text { realizadas exclusivamente para estos aparatos las } \\
\text { que presentaban vistas panorámicas o el detalle } \\
\text { de una gran variedad de temas, su producción y } \\
\text { distribución alcanzó hasta la segunda mitad del } \\
\text { siglo XIX cuando fueron reemplazadas por tomas } \\
\text { fotográficas y la popularidad del aparato no } \\
\text { mermo hasta bien entrada la segunda década del } \\
\text { siglo XX. }\end{array}$ & \\
\hline $\begin{array}{l}\text { Cédula pantalla } 14.9 \\
\text { Caleidoscopio } \\
\text { En } 1815 \text { el científico y naturalista escocés David } \\
\text { Brewster inventó el caleidoscopio un aparato que } \\
\text { se valió de espejos para lograr un efecto óptico de } \\
\text { multiplicación que permitió la reproducción de un } \\
\text { número ilimitado de dibujos simétricos y } \\
\text { cambiantes. Este invento consistía en un cilindro } \\
\text { en cuyo interior y a todo su largo se encontraban } \\
\text { dos espejos en } 45 \text { grados; al fondo del tubo había } \\
\text { un depósito en el que se encontraban pequeños } \\
\text { trozos de cristal pintados y en el otro extremo un } \\
\text { diminuto orificio a modo de visor. Al observar su } \\
\text { interior y al hacer girar el cilindro, las formas y } \\
\text { colores se multiplicaban gracias a los juegos de } \\
\text { espejos y de las decenas de fragmentos } \\
\text { multicolores. Inmerso en pleno desarrollo } \\
\text { industrial, se afirmaba que la belleza estaba } \\
\text { regulada por el equilibrio que se podía observar en } \\
\text { la naturaleza, misma que debía predominar en las } \\
\text { artes. Con la creación de este aparato y la } \\
\text { producción seriada de infinitas imágenes iguales, } \\
\text { se podría decir que el caleidoscopio respondía } \\
\text { muy bien a las ideas de eficiencia y productividad } \\
\text { que dominaron en el siglo XIX. }\end{array}$ & $\begin{array}{l}\text { Referencia Francisco } \\
\text { Frutos } \\
\text { http://www.museodel } \\
\text { aluz.unam.mx/exposic } \\
\text { iones/talleres }\end{array}$ \\
\hline $\begin{array}{l}\text { Cédula pantalla } 14.10 \\
\text { Visor estereoscópico } \\
\text { El origen del visor estereoscópico se instala en } \\
\text { pleno proceso de indagaciones fisiológicas de } \\
\text { principios del XIX, ya que dichas investigaciones } \\
\text { permitieron determinar que cada ojo recibía una } \\
\text { imagen independiente del otro, siendo el cerebro } \\
\text { el órgano encargado de recomponer la imagen } \\
\text { que ambas fotografias proyectaban. A este } \\
\text { fenómeno se le llama disparidad binocular y es } \\
\text { gracias a él que podemos tener percepción de la } \\
\text { profundidad de campo. } \\
\text { (Texto saber más: El 3D llegó a CALIWOOD } \\
\text { Un directivo del Museo de la Cinematografía } \\
\text { "descubrió", en un anticuario, un tesoro histórico } \\
\text { y lo entregó a CALIWOOD para incrementar los }\end{array}$ & $\begin{array}{l}\text { Imagen de referencia } \\
\text { Caliwood } \\
\text { Texto saber más } \\
\text { Caliwood: } \\
\text { https://www.faceboo } \\
\text { k.com/CaliwoodMuse } \\
\underline{\text { ocinematografia?fref }} \\
\text { =ts }\end{array}$ \\
\hline
\end{tabular}


juegos ópticos del siglo XIX que poco a poco, con asistencia de terceros, están llegando al joven Museo. Se trata del 1er aparato con el que se pudieron apreciar imágenes en $3 \mathrm{D}$, merced a un concepto de 1838 . El elemento, conocido como el Perfecscopio, tiene cualidades estereoscópicas y fue inventado por el escocés Sir Charles Wheatstone. Su cuerpo, fabricado en aluminio y adornado con diseños Art Noveau, posee dos visores de cristal que permiten ver, con absoluta nitidez, imágenes tridimensionales sin la asistencia de un proyector de cine moderno como sucede en el 2013. El Perfecscopio de CALIWOOD fue patentado el 15 de octubre de 1895 y presentado en la Exposición Universal de París en 1900. El aparato no poseía las fotografías apropiadas para apreciar el 3D, pero gracias a la gestión del señor Jorge Eliécer González Martínez de Pasto, se consiguieron 3 retratos de 1901 con los que los interesados pueden observar cómodamente las tres dimensiones).

\section{Cédula pantalla 14.11}

Linterna mágica

La linterna mágica consistió en una caja de madera o metal en cuyo interior se encontraba una fuente de luz - al principio una vela, luego gas y más tarde una ampolleta eléctrica -, en su cara frontal se hallaba un tubo con un lente en cada extremo; al acoplarse el tubo al cuerpo de la cámara quedaba una ranura en la que se colocaban unas pequeñas placas de cristal translúcido a través de las que pasaba la luz del interior del aparato para salir proyectadas por el extremo opuesto del tubo

\section{Cédula pantalla 14.12}

Fantasmagoría

El dominio sobre la "mecánica oscura" dio pie a la creación de un espectáculo que marcó la mayoría de edad de la linterna mágica: las fantasmagorías. La fantasmagoría dotó de movilidad a la linterna mágica al incorporarle ruedas, de esta manera con un movimiento hacia adelante o hacia atrás la imagen aumentaba o disminuía según las necesidades del linternista. A la linterna móvil se sumaron otras linternas estáticas que permitieron generar efectos de sobreimpresiones, fundidos y apariciones fantásticas.

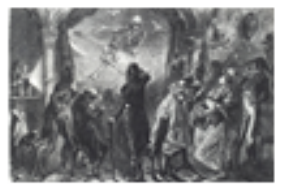

Linterna mágica José

Martín Roldan

https://www. voutube

.com/watch?v=hKsUiK

r00y8

http://www.caliwood. com.co/linternasmaacutegicaslaacutempara-deaceite.html

https://www.youtube .com/watch?v=S9hVV $\underline{\text { LOHdTI }}$ 
El clérigo belga Étienne-Gaspard Robert, conocido como Robertson reparó en el interés que generaba el abordaje de temas espectrales en la sociedad de fines del siglo XVIII y principios del $\mathrm{XIX}$, así fue como creó un género audiovisual que tuvo a la muerte como la principal fuente de inspiración. En el complejo entramado técnico de las fantasmagorías convergían distintos medios a la hora de generar sobreimpresiones, fundidos, apariciones fantásticas y atmósferas sonoras, a la ya mencionada linterna rodante, debe añadirse otra "normal" que proyectaba figuras estáticas; la utilización del humo como otra superficie sobre la que reflejar la trama; instrumentos musicales, trucos y variados dispositivos creados para ambientar de manera audible las escenas, amén de la propia voz del linternista. Este conjunto de elementos consolidó un género audiovisual que sobrepasó por mucho a los espectáculos de linterna mágica que lo precedieron, incluso llegó a inspirar a los primeros directores de cine primitivo no solo en la temática sino que también en los recursos técnicos con los cuales llegar a desarrollarla. 


\section{BIBLIOGRAFÍA}

Anónimo (2007), "La columna de Marco Aurelio", en URL: http:// www.historiaclasica.com/2007/02/la-columna-de-marco-aurelio.html, última consulta el 29 de abril de 2013

Arango, Leonidas (2005), "Los amores del Quelif, última producción silente en Colombia”, en Leonidas Arango, Sociedad, cultura e imagen: Desolvidos del Líbano (T.), Bogotá, Editorial Bochica.

Arbeláez, Ramiro (2002), "EL cine en el Valle del Cauca", en URL: http:// dintev.univalle.edu.co/cvisaacs/index2.php?option=com_content\&do_pdf=1\&id=465, última consulta el 30 de abril de 2013.

Arias, Juan Carlos (2006), "El cine como realización del fin del arte”, Signo y Pensamiento, vol. XXV, julio-diciembre, pp. 101-111.

Armell, Montserrat y Antonio Esquerro (2003), "Música e imágenes hasta la llegada del cine. (Linterna mágica, armónica de cristal, fantasmagorías y teatro de sombras)”, Anuario Musical, 58, pp. 279-353, URL: http://anuariomusical.revistas.csic.es/index.php / anuariomusical/article/view/77/78

Azéma, Marc y Florent Rivère (2012), "Animation in Paleolithic art: a pre-echo of cinema", Antiquity, vol. 86, núm. 332, pp. 316-324.

Balter, Michael (2002a), "From a Modern Human's Brow-or Doodling?”, Science 11, vol. 295, núm. 5553, enero, pp. 247-249

(2002b), “What Made Humans Modern?”, Science 15, vol. 295, núm. 5558, febrero, pp. 1219-1225.

Bandy, Mary Lea (1994), "El cine en el Museo de Arte Moderno de Nueva York: el primer museo cinematográfico de los Estados Unidos", Museum Internacional, vol. XLVI, núm. 4, pp 26-31

Burns, Paul (2010), “Chapter One. 900 BC-AD 1399”, The History of the Discovery of Cinematography, URL: http://www.precinemahistory.net/900.htm, última consulta 29 de abril de 2013.

Ceram, C.W (1965), Arqueología del cine, Barcelona, Ediciones Destino.

Crary, Jonathan (1988), "Modernizing vision", en Hal Foste (ed.), Vision and Visuality, Seattle, Bay Press, pp. 29-50. 
Crary, Jonathan (2008) ?1990? Las técnicas del observador. Visión y modernidad en el siglo XIX, Murcia, Centro de Documentación y Estudios Avanzados de Arte Contemporáneo.

Diario ABC (2013), "Así se moverían las pinturas rupestres si cobraran vida” (anónimo), URL: http://www.abc.es/ciencia/20130110/abci-moverian-pinturas-rupestres-cobraran2013011 01252.html, última consulta 25 de abril de 2013.

El'Gazi, Leila (1999), “María (Máximo Calvo)”, Credencial Historia, núm. 112, abril, p. 4.

Frutos, Francisco (2009), “Historietas mágicas: Orígenes del relato gráfico y proyección de imágenes”, Diálogos de Comunicación, no 78, pp. 1-11.

(1996), La fascinación de la mirada. Los aparatos precinematográficos y sus posibilidades expresivas, Valladolid, Junta de Castilla y León.

Frutos, Francisco y Carmen López (2010), “La fantasmagoría como género audiovisual”, II Congreso Internacional Comunicación y Desarrollo en la Era digital, 3-5 de febrero de 2010, Málaga, Asociación Española de Investigación de la Comunicación.

(FPFC) Fundación Patrimonio Fílmico Colombiano (2012), Historia del cine colombiano, Bogotá, Fundación Patrimonio Fílmico Colombiano.

(2012), Arqueología del cine y periodo silente de la cinematografía colombiana, Bogotá, Fundación Patrimonio Fílmico Colombiano, Alcaldía Mayor de Bogotá.

------ (2012), Colección Cine Silente Colombiano, Bogotá, Fundación Patrimonio Fílmico Colombiano.

------ (2011), “Ficha Técnica de Flores del Valle, versión restaurada”, URL: http://www.patri moniofilmico.org.co/anterior/noticias /010.htm, última consulta 30 de mayo de 2013.

------ (2009), Luces y sombras, Bogotá, Fundación Patrimonio Fílmico Colombiano.

------ (2006), Largometrajes colombianos en cine y video, Bogotá, Fundación Patrimonio Fílmico Colombiano.

------ (2006), “Historia de la Fundación Patrimonio Fílmico Colombiano”, URL: http:// www.patrimoniofilmico.org.co/index.php? option=com_content\&view=article\&id=50\&Itemid=59, última consulta 30 de mayo de 2013.

------ (2001), Alma provinciana de Félix Joaquín Rodríguez, 1926. Versión restaurada, Bogotá, Fundación Patrimonio Fílmico Colombiano.

Galarza, Joaquín (1997), “Los códices mexicanos”, en Arqueología Mexicana, núm. 23, enerofebrero, pp. 6-13. 
Galindo, Yamid (2003), "Garras de Oro: Un film silente y político sobre la perdida de Panamá”, Historia y espacio, núm. 20, enero-junio, p. 119-134.

Gatton, Matt (2012), Paleo-Camara. The Start of Art, URL: http://www.paleo-camera.com, última consulta 9 de mayo de 2013.

Gómez, Rafael (2002), "La comedia de magia como precedente del espectáculo fílmico", Historia y Comunicación Social, Vol. 7, pp. 89-107.

-------- (1998), “Precinematografía Infantil”, Secuencias, no9, pp. 45-54

Gotor, Pablo (2010), "Del precine al postcine. Fantasmagoría y el cine digital”, en Jordi Pons, Monstserrat Puigdevall (coord.), Un arte de espectros: magia y esoterismo en el cine de los primeros tiempos, Girona, Ayuntamiento de Girona, pp. 183-190.

Gubern, Román (1996), Del bisonte a la realidad virtual. La escena y el laberinto, Barcelona, Anagrama.

Herzog, Werner (2010), La cueva de los sueños olvidados, Canadá-Estados Unidos-Francia, Creative Differences, DVD.

INAH (Instituto Nacional de Antropología e Historia) (2007), Persia: fragmentos del paraíso. Tesoros del Museo Nacional de Irán, México, INAH.

Jansen, Maarten y Gabina Pérez (2000), La Dinastía de Añute, Leiden, Leiden University.

Konisberg, Ira (2004), Diccionario técnico Akal de cine, Madrid, Akal.

Laverge, Yves (1994), “Cien años de cine”, Museum Internacional, vol. XLVI, núm. 4, pp. 5-7.

Lizarazo, Diego (2008), “Encantamiento de la imagen y extravío de la mirada”, en Diego Lizarazo (coord.), Sociedades Icónicas, México DF, Siglo XXI, pp. 33-50.

Lizcano, Martha y Danny González (2006), “Carnaval de Barranquilla: De Floro Manco a la UNESCO. 100 años de patrimonio cultural inmaterial en el documental”, Revista Brasileira do Caribe, vol. VII, núm. 13, julio-diciembre, pp. 169-196.

MNC (Museo Nacional de Colombia) (2007), ¡Acción! Cine en Colombia, Bogotá, Museo Nacional de Colombia.

Moreno, Jorge y Rito Torres (2011), “Cronología de la llegada del cine a Colombia (18971899)”, en URL: http://www.patrimoniofilmico.org.co/anterior/noticias/040.htm, última consulta el 30 de abril de 2013.

52

Osorio, Oswaldo (2005), Comunicación, cine colombiano y ciudad, Medellín, Universidad 
Pontificia Bolivariana.

Païni, Dominique (1994), "La ?ascasa del sueño colectivo”, Museum Internacional, vol. XLVI, núm. 4, pp. 11-13.

Proimágenes (Fondo Mixto de Promoción Cinematográfica) (2013), "Al son de las guitarras", URL:http://www.proimagenescolombia.com/secciones/cine_colombiano/

peliculas_colombianas/pelicula_plantilla.php?id_pelicula=21, última consulta 20 de mayo de 2013.

Ramírez, Margarita (2004), La ilusión en el arte. Del Renacimiento a la realidad virtual, Addenda, núm. 7.

Salcedo, Hernando (1981), Crónicas del Cine Colombiano 1897-1950, Bogotá, Carlos Valencia Editores

Sontag, Susan (2006), Sobre la fotografía, México D.F, Santillana Ediciones Generales.

Suárez, Juana (2009), Cinembargo Colombia. Ensayos críticos sobre el cine y cultura, Cali, Editorial Universidad del Valle.

---------, Ramiro Arbeláez (2010), “Una muda conspiración contra Roosevelt: garras de oro (The dawn of justice)”, Nexus, núm. 7, pp. 93-100.

Torres, Rito (2011), “Exposición Cine silente colombiano. Sonorización del patrimonio audiovisual colombiano por músicos uniandinos”, Skéne, núm. 1, pp. 20-27.

Wasson, Haide (2005), Museum Movies. The Museum of Modern Art and the Birth of Art Cinema, Berkeley, University of California Press.

Zarco Sánchez, José Luis (2010), "De lo científico del registro a lo fantasmagórico de su proyección”, en Jordi Pons, Monstserrat Puigdevall (coord.), Un arte de espectros: magia y esoterismo en el cine de los primeros tiempos, Girona, Ayuntamiento de Girona, pp. 191-197. 
